Illinois State University

ISU ReD: Research and eData

Theses and Dissertations

3-16-2016

\title{
Queer Horizons: Queer Assemblages and (Re)Visioning the "Coming-Out" Trauma Narrative in Fiction, A Critical Introduction
}

Eric Jason Pitman

Illinois State University, epitman@ilstu.edu

Follow this and additional works at: https://ir.library.illinoisstate.edu/etd

Part of the Creative Writing Commons

\section{Recommended Citation}

Pitman, Eric Jason, "Queer Horizons: Queer Assemblages and (Re)Visioning the "Coming-Out" Trauma Narrative in Fiction, A Critical Introduction" (2016). Theses and Dissertations. 537.

https://ir.library.illinoisstate.edu/etd/537

This Thesis is brought to you for free and open access by ISU ReD: Research and eData. It has been accepted for inclusion in Theses and Dissertations by an authorized administrator of ISU ReD: Research and eData. For more information, please contact ISUReD@ilstu.edu. 


\title{
QUEER HORIZONS: QUEER ASSEMBLAGES AND (RE)VISIONING THE “COMING-OUT” TRAUMA NARRATIVE IN FICTION, A CRITICAL INTRODUCTION
}

\author{
Eric J. Pitman
}

\section{Pages}

The experience of many queer subjects in "coming-out" often results in a great deal of continued adversity over the course of their lifetimes, in spite of what popular, exceptionalized narratives such as the "It Gets Better" campaign might suggest. "Coming out" often entails a great deal of trauma, thus making the need to continue "coming out" a source from which anguish continues to emanate and affect queer bodies. Unfortunately, there are few fictional texts dealing specifically with "coming-out" trauma narratives. Queer subjects who continue to endure trauma through the act of "coming out" often discover that the written worlds of their experiences are either recklessly optimistic, or cruel and inhospitable. This project seeks to begin a new conversation towards addressing the great lack of visibility concerning "coming-out" trauma narratives in works of fiction, and it seeks to define a possible means of developing literary works that can resolve this absence.

KEYWORDS: Queer, Trauma, Fiction 
QUEER HORIZONS: QUEER ASSEMBLAGES AND (RE)VISIONING THE “COMING-OUT” TRAUMA NARRATIVE IN FICTION, A CRITICAL INTRODUCTION

ERIC J. PITMAN

A Thesis Submitted in Partial

Fulfillment of the Requirements for the Degree of

MASTER OF SCIENCE

Department of English

ILLINOIS STATE UNIVERSITY

2016 
Copyright 2016 Eric J. Pitman 
QUEER HORIZONS: QUEER ASSEMBLAGES AND (RE)VISIONING THE “COMING-OUT” TRAUMA NARRATIVE IN FICTION, A CRITICAL INTRODUCTION

ERIC J. PITMAN

COMMITTEE MEMBERS:

Ricardo Cortez Cruz, Chair

Kass Fleisher 


\section{CONTENTS}

CONTENTS

\section{CHAPTER}

I. CRITICAL PREFACE 1

II. (RE)COMBOBULATOR 22

$\begin{array}{ll}\text { III. DINNER PARTY } & 47\end{array}$

$\begin{array}{lll}\text { IV. BIRTH CARNIVAL } & 77\end{array}$

V. COSMOS T(EX)T MACHINA 87

$\begin{array}{ll}\text { REFERENCES } & 119\end{array}$ 


\section{CHAPTER I}

\section{CRITICAL PREFACE}

Although there may seem to be an increase in the presence of fictional works featuring queer protagonists, there exists still an immense lack of texts which, in particular, detail the traumatic experiences such queer subjects endure when "coming out.” Lies Xhonneux, a Life Writing and Queer Studies scholar, illustrates such a claim by asserting that "coming out stories are often perceived simply as a description of individuals who come to adopt a non-heterosexual identity" (95). Whether individuals undergo a nourishing, safe "coming out" or not, they must still learn to find their way and continue doing so, as the queer subject's reality is that one must adapt to a world that remains rife with heterosexual norms, cruelty, and disparities of many orders ad infinitum, and that many spaces confront queer individuals with hostility and persistent duress. In addition, exceptionalized "coming-out" narratives emblazoned with the glamorous "It Gets Better" slogan may only contribute to eclipsing the reality that there exists a disturbing absence of alternative narratives that directly confront the various social, emotional, bodily, and spiritual crises that a queer subject may face over the course of a lifetime after the initial public "coming out."

Exploring alternative "coming-out" narratives is of utmost importance to myself, queer individuals, and the body of literature at large, simply for the fact that I have not seen any fictional work that so intimately engages this particular struggle on multiple 
fronts. "Coming out" and having to live with it isn't easy, and it often doesn't get better. Many queers seem to feel like it hasn't been worth it, and this is one particular reality that "coming out" narratives as a genre have failed to acknowledge. I've had to confront how "coming out" means differently, depending on the situation, depending on how I want to see and make meaning of myself, whether it is for myself or for others. As a writer, I can choose to make "coming out" mean something different for myself, as the pain attached to it is fixed in the past, but my perceptions of that pain possess a capacity to dramatically change over time. In seeking new meaning for the material world, I have often fixed it within the immaterial. I use my own dream-spaces as a site through which speculative performances of the material might play out in relation to the performances fixed within the real.

This concept has revealed to me that in relation to my own trauma, meaning can be quite diverse, unpredictable even. I can potentially choose which meaning is the most significant. Narratives capable of communicating this deeply personal, shared belief may not always enjoy stability, as one's needs and personalized configurations of trauma factor into the shaping of work, allowing for potentialities in which protagonists succeed, but more importantly fail to define trauma with meaningful language. In pursuing this idea, authors generating alternative "coming-out" narratives informed through persistent trauma will seek to find spaces where failure is certain, or resolutions where there exists only the possibility for reconciliation.

As is similar to my own experiences as a queer subject, such works which seek futile reconciliations of trauma within the queer subject should articulate the ordeal as an ongoing process, not just a singular, easily articulated and confined experience. As 
Xhonneux insists that "coming out stories and concepts like 'the closet' should not be read simply as reproducing a preexisting identity: more often than not they produce it too" (96), I maintain that, in narratives of "coming-out" trauma, identity is shaped and reshaped in a feedback loop. A multitude of forces and incarcerating concepts impinge on the development of one's queer psyche. As such, these fictional works must feature a protagonist consciousness shifting between metaphysical and physical terrains. Our consciousness (the queer subject) is immersed and enmeshed within a complex array of structures, entities, individuals, and subversive powers. At both the macro and micro levels, such an apparatus is demonstrably massive. Its influence extends beyond the material world. In the real world, queer bodies are moved and controlled. In the isolation of our silence, we pass into the metaphysical, explore psychological spaces where the intimate ontologies of our suffering becomes rooted and symbolized. Intimately tethered to these ontologies is the great absence of who we are-not only in a lack of selfawareness, but in the utter physical lack of simply seeing ourselves reflected in books, our pain communicated, our experiences shared.

Shifting between such physical and metaphysical spaces must be considered for producing works of fiction that seek to represent and critique the manifold oppressions thrust upon the queer subject, resulting in "coming-out" trauma. Yet, a binary of presence/absence suffers limitations in its operative capacity for examining the complexities that identity, bodies, ages, materialities, archetypes, and objects produce interactionally within traumatized bodies and consciousness. Queer individuals make use of these dynamic factors in the shaping of their identities. We focus on articulating how "coming-out trauma" contributes to this formation (or lack thereof) in fictional 
protagonists. "Coming-out trauma" requires that such characters feature a high degree of malleability and transformativity. Specific identity labeling of the protagonist must also shift (due to the unhuman quality of such a character). The protagonist may not even have a name. They might not have a body. I argue for work where protagonists are seen as shifting in space, name, and body. After all, the development of such things in pure queer fashion are forbidden by the human. Additionally, the body of queer literature desperately calls for a diversifying of the ways in which scholarship addresses such specific, complex concerns of queerness as the "coming out" narrative.

Protagonists must travel through a tenuous fluid of Being that is stratified by space, time, tactility, clarity, confusion, organization, disarray, rage, confusion, and parody. I myself can attest to the queer subject seeking to locate a viable "way out" through various methods of organizing and reorganizing oneself for the purposes of attempting to define or explain one's own "coming-out" trauma, whether it be through memories, dreams, objects, spaces, and time. Affordances must be given to protagonists for a particular analyzing or "personalized accounting for" one's epistemic knowledge, for one's futurity. These queer characters are cast against forces of oppression and domination - this is intrinsic to "coming-out" trauma as a constant reminder. However, our storyworlds are more effective when they drive the notions of queer assemblages towards a framework where the aforementioned necessities for queer protagonists and their "coming out" trauma materialize.

In her work regarding queer assemblages, Professor and queer theorist Jasbir Puar provides one such transformative avenue, rightly pointing out, "Displacing queerness as an identity or modality that is visibly, audibly, legibly, or tangibly evident, assemblages 
allow us to attune to the intensities, emotions, energies, affectivities, textures as they inhabit events, spatiality, and corporealities" (521). What we should desire are protagonists that can be seen as entering various assemblages of mind-space, time-space, and reality-space in relation to trauma-imbricated bodies and object(s), as well as object(s) and body-induced trauma. This movement fulfills the purpose of either cathartically or recklessly acquiring a new manner of speaking about one's own being. In the prison of one's own anguish in being unable to give voice to the experience of “coming out" (and not once, but over and over again), movement liberates, and language vindicates.

In Terrorist Assemblages, Puar constructs the queer subject as not entirely human, but unhuman, as an unlegal entity purposed for the tactical advantage of instituting societal control. In this state, the body from which identity markers have been withdrawn signal one variation of a biopolitical shift from disciplinary control mechanisms that police bodies, to those of incomprehensibility and thus illegibility under the definitions of human. In the unhuman, Puar asserts that power works through the porosity of material bodies rather than through the discretion of categorical identities that collectively measure against an ideal human. The human, or heterosexual, in the context of what narrative fiction's predominant protagonist looks like, controls the discourse or narrative of what it means to live, die, experience pleasure, marry, pass through the world, form relationships, experience grieving, loss, etc., while the unhuman, i.e., queer, is normally prevented from entry into those categories. Halted from a visible grieving, these unhuman forbidden must strategically conform to the language of the heterosexual, and thereby commit a persistent violence upon themselves in ritualistic collaboration. Just to be 
visible. For this reason, "coming-out" narratives tend to placate heterosexual readers, rather than exposing them to the true, cataclysmic nature of the traumatic forces rendered upon the queer subject's psyche.

Queer fiction is at its best when creating protagonists who are wrestling with a burgeoning psychology of death, desire, and sexual identity. These protagonists may in fact perceive their own unhuman-ness, or perhaps recognize the power which issues forth from structural entities, institutions, authority figures. In this sense, they pass between perceived realities and dream states in which memories, comforts, fears, words, sounds, spaces, sensations, time, and alternate phase-states of the self, other characters, and objects materialize, cluster, and interlock within specific settings. A transforming of the protagonist or these exterior forces issuing forth occurs in response to the protagonist's existential anxieties and shifting epistemological stance. What is learned affects the shape of what happens next, and what happens next clearly affects the way in which a protagonist self-actualizes or not. Trauma moves, teaches, ruptures, and scorns well beyond its moment of inception. This specific set of criteria comes as potential anathema to the human, but righteously so.

In order to articulate these assemblages through protagonist subjectivity, it is crucial that queer creative work explore various landscapes in macro and micro fashion. For example, a protagonist may become microscopic and survey the condition of a protagonist's own cells, DNA, or interstitial fluids. Perhaps a protagonist may opt to immerse within subconscious repressed memories, travel through multiple dream landscapes to construct a representation for a narrative moment intended as "real." Puar's work in assemblage theory complicates what is normally considered to be the "body" and 
"identity" in definitive terms, arguing that "assemblages allow us to attune to intensities, emotions, energies, affectivities, textures as they inhabit events, spatiality and corporealities" (520). Partially dedicated to exploring the ways in which terrorist bodies are displaced by the transnational deployment of queer American exemplars, her work describes how Middle Eastern bodies are queered in the context of necropolitics. Within the borders of the U.S., the heterosexual matrix constructs its own death spaces for the queer unhuman, whether they be real, physical spaces, or ghostly terrains of torment that haunt the mind and body.

As the infinite position of America-at-war has given way to a new modality in which the identity/body of the suicide bomber, for example, is written into "a perverse habitation of contradiction" (521), this collapsing allows for a space where the body and one's identity might be transformed and inscribed by context-specific political discourse. These concepts can contribute handsomely to narrative work focused on upending the traditional "coming-out" narrative through imaginative reformulations, in their insistence that "temporal narratives of progression are upturned as death and becoming fused into one" (521). These shifting assemblages, spaces, and passages of time, and the various dynamics occurring within them in regard to theme, metaphor, voice, image, tactility, sound, etc., at their best represent the internal psychological mechanisms of protagonists. Such mechanisms co-habitate a peculiar, seemingly contradictory arc that culminates in the simultaneous destruction/creation of the self in these various material and immaterial landscapes. In story-space, this duality might be seen as an attempt to find new language in the face of continual trauma as it proceeds forth from its various sites of immanence. In other words, as I have felt my own traumatic experiences being summoned forth and 
determining my actions, I have also dreamed of such experiences and actions in different ways. In this instance, I see embodied knowledge at work in my own personal life.

Incorporating the material and immaterial into a work focused on rearticulating "coming-out" narrative, focusing on trauma, also involves the terrains in which such traumatic activity occurs. In relation to protagonist subjectivity, such terrains can be described as shaped, constructed, and altered by both the 'objectness' of objects, and those objects imbued with significance. To be more specific, objects exist as consciously selected for representation of trauma (for various purposes by the subject), and this intuits other objects via their own exterior material agency. The latter of the two have startled within the protagonist some signification of trauma (or recognition of inaccessible interiority, i.e. the repressed and withdrawn subject). I see my own body and memory as affected and interacting with objects in relation to my own sense of needing to figure things out. We give meaning to objects, or objects stir a memory. Objects are revisited. They create new meaning.

In this case, a queer protagonist created by an author experiences evocation of their trauma - an unwanted remembrance of it, whereby some form of re-enactment occurs, or the trauma re-subjectifies within the "host" and transmits new meaning. Often, when interacting with memories and objects concerning my own "coming-out" narrative, I find myself experiencing an odd mixture of these examples as I negotiate old pain, feelings of absence, unfairness, or as I attempt to make new meaning of my own history in regard to where life has taken me. These negotiations plague the quality of the protagonist's experiences - a trauma-induced discursivity that "coming-out" narratives should seek to elucidate through the use of queer assemblages. 
As a queer subject navigating the world within and without, my trauma exists as one such assemblage where it possesses its own agency to affect me. It shapes and reshapes how I see the past and present in physical and metaphysical spaces outside of what I would consciously allow it to do. It retains the power to also impinge upon how I perceive the future, and this imposition extends beyond my dream-and-awake state into the unknown. What I perceive as a viable future is constantly threatened by the continuing presence of what has happened to me. I experience this as something beyond a memory. It is in my body, my mind, in my future actions.

For instance, in the theory of Lee Edelman and Jose Esteban Muñoz, alternative, impending "ends" or feelings of uselessness reverberate in the imagination from some unknown point lying in wait. Re-tooled "coming-out" narratives may explore memory, but they may also employ both the real and imaginary for the purpose of expressing heightened levels of awareness. As Muñoz asserts, "the not-quite-conscious is the realm of potentiality that must be called on, and insisted on, if we are ever to look beyond the pragmatic sphere of the here and now; the hollow nature of the present ... queerness is not quite here; it is, in the language of Italian philosopher Giorgio Agamben, a potentiality" (21).

“Coming out" as a continual process involves many different kinds of difficulties resting in potential. Trauma-informed narrative then, as a tool for reconceptualizing “coming-out,"-its specific representation-finds movement between one's past and future potentialities. It isn't fixed in either the interior or exterior, nor between the human and unhuman, but, in true queer fashion, is capable of traversing multiple terrains. It must exist in multiple terrains, as the queer subject, especially in their self-enacted 
rehabilitation, will not be a simple derivative of heterosexual hegemony. The queer subject, imaginatively hypothesized, transcends this dyad and formulates new pathways for understanding the self.

Removed in some part, trauma retains some agency to affect, thus complicating this process. Simultaneously, this trauma is located within and written upon the material body, irrevocably affecting which potentialities might be conceptualized. Therefore, this particular nuance of trauma creates the feeling that the future is always under some kind of threat, a potent, core manifestation of "coming-out" trauma. It impels the belief or feeling that no future or potential of futures is waiting. It isn't accepting of queer minds and bodies, and such a spaces' viability must be imagined, if possible. The task often seems incomprehensible.

Narratives of "coming-out" trauma further complexify as they rely on the performative actions informed by such trauma, which in turn portend new versions of the "coming-out" narrative, particularly if they are written through assemblage, must be articulated with material consequences in mind, particularly on the body and mind of the author. Queer theorist Judith Butler places performativity under the analytical lens, acknowledging how the role of materiality leads to an unreconciled (still, as of now) tension between the body and what is "performed" in terms of identity. However, Jay Prosser, in focusing on transsexual representation, challenges some of Butler's assertions regarding the material body collapsed into the psychic projection. He advocates instead that ownership of the body, gender and sexual identity is relinquished to mere fantasy in this deliteralization of sex. Prosser contends that desire is thereby divorced from any physical or embodied knowledge and relegated to a melancholic configuration embedded 
within the psyche. Beyond the separation, the desires of the unhuman would not likely be acknowledged as such in the first place. Such repressed or forbidden desires remain confined to the internal, the unresolved.

Prosser notes, "because the subject often speaks of the imaginary body as more real or more sensible, I argue that this phenomenon illustrates the materiality of the bodily ego rather than the phantasmatic status of the sexed body: the material reality of the imaginary and not, as Butler would have it, the imaginariness of material reality" (46). The internalization then is a construction in which the referent(s) are first cited from material stimuli (the body, the inward, what one feels) as opposed to the reverse where interiority relies on the exterior performance. For the unhuman, such a performance often sadly mirrors a capitulation to the human's peace of mind. Queers perform for heterosexuals - we do what is permitted within the sanctioned playground of comfortability.

Between performativity and materiality—the implications that this site of tension within the body of queer literature suggests - considerations must include the performative act of writing one's own embodied "coming-out" trauma via creative, imaginative narrative, by bringing it from an internalized bodily space and into physical existence. Re-imagining the "coming-out" narrative through trauma is an act that paradoxically re-inscribes the trauma. Even so, in its act, the author seeks to imagine a way out. Of key distinction here are the diverse ways in which negotiations are made between performativity and materiality, with regard to crafting a narratological space where full variation—even at the expense of comprehension—of vision, embodiment, and futurity as affected by "coming-out" trauma might unfold. 
Many assumptions destabilize over the course of a text, but protagonist identity needs to be inferred as queer. Readers may arrive to their conclusions about protagonist identity at the onset because of how a narrator/character may describe their body/identity interacting with the spaces around them, but these facets certainly change, at least in reality. Observations, sensations, and the details recorded by the protagonist's narrative account are of importance, as they possess the potential to seem so inhospitable to some readers since they obstruct meaningful communication.

This barrier in recorded experiences leads to questions regarding reader accessibility. In the insider/outsider perspective taken up in Jodi Kaufmann's work, and taken up in other queer studies which seek to locate equitable representations for queer subjectivities and embodiment contest that as identities and ideas about ourselves do not arise in vacuums, as they are shaped in social spaces, the question of authenticity should be investigated. No one has a complete monopoly on their experiences, though the conundrum remains in regard to who owns the narrative. Who owns the representation, especially if it is one so transmogrifiable? In addition, the stakes are high when the erasure of identity threatens equitable theorizations of how queer subjectivities should be represented in terms of embodiment.

Such particularities seem to be crucial in parsing out if one wishes to specifically engage the issue of embodiment within "coming-out" narratology. I contest that there may (and should) be deliberate antagonism on part of the author so as to confuse the reader into failing to properly orient themselves about the character they are reading. Literary critic Wayne Booth notes that when the verisimilitude of a text is deliberately 
manipulated, the tactic often works quite effectively toward leading a reader to reflect on their own subjectivity.

He describes such a relationship between the reader and a text as "when the narrator's bewilderment is used not simply to mystify about minor facts of the story but to break down the reader's convictions about truth itself, so that he may be ready to receive the truth when it is offered to him" (285). Despite whether or not Booth is specific enough here with his usage of the term "truth" (whether it be from the narrator's perspective or not), the truth the character believes and communicates to the reader, or the verisimilitude of the reality of the fictional work itself is not in question. What is pertinent is whether the author, if making use of the violent oscillations in identity and embodiment some of the aforementioned works in queer-assemblages deals with, has decided whether or not, and to what degree, the work fruitfully harms their reader.

All of this begs the question: what is it the unhuman should say to the human? When the unjustly convicted and tormented hold their tormentors' (intentional or complicit) captive, what is said? At the very least, authors generating narrative informed by "coming-out" trauma that seeks to re-conceptualize trauma (particularly when considering the traumatic act of writing itself) must consider affecting their readers in similar manner. We are not heard until our pain is felt viscerally, experientially, as much as a text is capable of mustering.

Deception may be just as viable. Intrinsic to the pain we queer subjects often feel in terms of what we learn over the course of our lives is denied to us, the unhuman, queer authors may defiantly mislead a reader. We may choose to construct a queer character through which a heterosexual reader may find it difficult to interact with or engage with 
in terms of meaning-making. As Booth goes on to say, "Whether the answer is itself unequivocal or, as in many modern novels, deliberately ambiguous is irrelevant to the basic form of such reading experiences. The claim that there is no answer is itself an answer, so far as literary effect is concerned" (285-86).

However, what Booth says is not without its own issues. His ideas concerning what a work of fiction should do are often fixed, creating strict limitations which cloak the specific intent of an author, specifically, if there are political motivations behind the outright deception. Booth's position is one of a strictly male-lens, therefore his sentiments concerning the value-associations a reader might prescribe to a text, especially its characters or the narrator, do not necessarily invite one to make room for the notion that in the construction of a label, such as truth, a definitive male gendering has placed restrictions on precisely what that might mean.

For instance, as Booth writes concerning the "pleasure of collaboration," "The true value of forcing the reader to decipher lies in what such activity does to his attitude toward the story and its author" (302). If one were to consider that a text written from the perspective lens of embodiment, it might be pertinent to reorient one's interrogation of the text apart from collaboration. There is little collaboration between the human and unhuman, but there is plenty of room for instruction. Instruction from the queer comes as a generosity to the heterosexual, but it is also instruction for the self. A remembering. A ritual of repeating and revisiting of one's injuries for the purpose of finding words to make them more significant than the presence of their wound, than the absence created in loss, in forbidden existence. A text written from such a space of intimacy might be too purely didactic for there to be much collaboration, but this teaching is justified in its 
reversal from the incessant collaborative demand hailed to the queer subject in every waking moment. The ways in which Booth polices various works under these sentiments and assertions might be considered intriguing to some, but it is quite restrained, if not severely crippled in being able to properly attend to the deceptive practices of authorship and storytelling that a queer author writing from a space of conflicted embodiment may adhere to.

Concerns of embodiment as set forth by a queer author may not, expectedly so, be an issue that we could rely on Booth to answer for us in terms of aesthetic value or truthfulness. He notes, in speaking of "pure art" that "both the quest for realism and the quest for purity, even in their most extreme forms, have yielded the same attack on rhetorical impurities in fiction ... If fiction is to seem real, it must not be laden with sign of artifice ... if fiction is to be pure, if it is to 'catch up with poetry,' ... the author must somehow find a way to create a cleansed object which can speak for itself" (96). Dramatic shifts in cultural sensibilities have significantly altered audience reception of works, even if they are considered "artistic" in contemporary terms. Authors today, it could be argued, must be even more cognizant of their audience. The world Booth speaks to is vastly different, yes, but his work isn't absent of some modicum of accuracy, particularly here. It goes without saying that what queer fiction can be and can do today is staggeringly different from Booth's era, but he is right to say, "whatever verisimilitude a work may have always operates within a larger artifice; each work that succeeds is natural—and artificial—in its own way" (59). Aesthetic appraisal of a work centered on queer-assemblage-informed concerns of embodiment is perhaps better off focusing on a shifting relationality between cogent details, coherency—the incoherent or 
metaphorically representational. In this regard, the aims of the author involve creating a work that mirrors the same incoherency of embodiment they experience or seek to represent in their work as real(ity). After all, where in the world of the human does the unhuman belong? The politicization of the text is immanent, in this regard.

Human readers (i.e. heterosexual) are implicated and bound to the agency of the unhuman's text.

For instance, an unhuman's fiction relays the protagonist's observations, sensations, speculations of futurity, etc. The author should therefore, according to Booth, be particularly conscientious of achieving some form of a natural-seeming discourse. The real state of the queer subject is quite the opposite. The unhuman is as such because we lack the natural as it is defined. Thus, we are conscientious of the unnatural-seeming discourses of the world, our own bodies and minds the tools by which we evaluate this facet.

Our bodies know the strangling clench of the words that exclude us.

This particular lens — this knowing — is useful in displacing misrepresentational assumptions about the stated "queering" of the protagonist or the text itself at large. The work will communicate the unnatural-seeming discourse of the unhuman, and this will forbid the reader from the act of conceptualizing a fixed meaning or truth concerning the protagonist's identity/embodiment. Booth's sentiments would thusly serve to remain in keeping with some queer theorists' sensibilities concerning methods of theorizing embodiment, but today's queer writer/righter should require these texts to push further. More specifically, authors may articulate landscapes or "facets" of identity that, when fractured, bear messages unable to completely permeate the strange membranes 
between them in translatability. For the queer subject, not everything that is dreamed, felt, or rendered in occurrence can be understood. The queer subject exists in terrain not purposed for their existence. The lack of understanding of the self, in addition to the absence of a capacity to rationalize one's own inner turmoil, falsifies reality. This artificiality, or a persistent inaccessibility to the true "authenticity" of things and events, finds itself exemplified in crucial interrogations at the center of these "coming-out" trauma narratives, a pair of questions I tirelessly ask myself: why does "coming out" still cause me to anguish, to feel unhuman, and will these feelings ever end? Is there a future where my memories and wounds are properly bandaged? These doubts must manifest throughout these narratives, seeking to extend the parameters of what is considered human, not only because the queer project of achieving variation might be met, but for the sake of expanding what it means to be human.

The fundamentals of story-space may issue from embodiment, structurally entangling objects, memories, comforts, fears, words, sounds, spaces, sensations, and time - all of these may be built into a lattice configured in what might be called an ontological queer-space or queer-assemblage. The subject of embodiment, when configured as projecting into alternate real spaces, constructs an unstable queer-alliance or re-combobulation, copying the instability of the author's subjective embodiment. Narrative theorist Seymour Chatman writes, in marking distinctions between written and visual, photographic narrative, "In verbal narrative, story-space is doubly removed from the reader, since there is not the icon or analogy provided by the photographed images on a screen" (101). Such removal only becomes complexified when metaphoric removals continue to be layered on top of story-space. That is the experience of the queer subject, 
particularly if they choose not to overtly perform their outness: removal after removal, from conversation, from inclusion, from consideration. A persistent, steady seepage of joy and hope plagues their mind and body—one little joy and hope after the next—in each occurrence of recognizing they don't belong, or in each moment of being forced to identify, this ebb contributing to the inner void, dread, and unresolved anguish, resulting in a phantasmal sepulcher of the psyche.

Whether "coming out" is to correct a misunderstanding, become included, or simply be acknowledge as human, it commits a violence in the act itself and upon the queer subject. Such violence — or some variation thereof, must be attended to in the text. Whether the violence is tactile — real or imaginary, or in a play — it becomes inherently connected to a reader's own physiology and conditioned as a reader orients oneself with a text. Attempting to procure facets of their own embodiment, readers strive to locate a "road map" through the narrative, but the endeavor fruitfully harms or unsettles, bringing into focus the queer subject's experience.

This orientation as it relates to the reader leads to an inevitable question concerning the accessibility of a text so hyperaware of its own discourse, whether that discourse's immanence exists through story-space or through the character (or whether story-space $i s$ the character). To echo Chatman, "Another restriction on character derives from a confusion between story and the verbal manifestation of discourse" (116). In order to articulate complex queer-assemblages through protagonist subjectivity, a work of fiction seeking to re-tool "coming-out" narrative through traumatized embodiment engages in a rhetoric beyond simply surveying obscure, strange terrains of queerness. It, 
much like the queer subject, projects multiple futurities, unsettles its observer. And, it completely mystifies.

This discombobulation seems to disregard plotting as an attractor for the character's traits or movement through a narrative, regardless of reader sentiments, interpretation, or ability to be guided by the author to some semblance of meaning. Chatman insists "a viable theory of character should preserve openness and treat characters as autonomous beings, not as mere plot functions. It should argue that character is reconstructed by the audience" (119). In a text exemplifying queer embodiment where character and story-space look to merge or become interchangeable, these narratological constraints impede the text. The relationship between plot and character is far more integrated - the story's path is potentially its own character. In this sense, the passage through turmoil takes a particular shape, one that stands apart but remains at one with the protagonist. In this sense, the reader must be aware of the desired finiteness or determined purpose of presence for the character(s)/story-space provided by the author.

Complicating the border between plot and character makes it clear that readers (particularly heterosexual readers) have to restrict their speculative tendencies when reconstructing a character, story-space, or meaning. Of course, it is inevitable that a reader will think or interpret beyond any limitations that an author might set forth in a text, making the intent of the author arbitrary to some degree. However, such a dynamic between queer-assemblaged character and story-space raises questions about whether or not that readerly interpretation is more so a product of the character as an open construct, as Chatman contends, or whether interpretation is due to the reader (the reader at most 
risk of alienation to the text) being dispossessed or limited, in terms of access, to the author's true, removed vision. The complex play between character and story-space may or may not be decisively connected to a determined culmination. There may be no attracting force to shape character. It is entirely possible that disjointedness is the overall aim. Or, it is the only reality, really, that we can yearn for.

Of course, social, cultural, historical forces impinge upon the not-completelywhole body or identity set within such a text. The desire for love, an undefined sense of want, lack, and the need for fulfillment through adventure - they all compete with an assured presence of death, disease, and cosmic callousness. While the intent of authors may be for these conflicts to be read as a metaphor(s), the reader should also interpret them literally. These particular realities might be often indicative of the doomed or unviable, but they aren't fixed and exist in an odd, shifting continuum of multiple realities that involve very real, tangible conflicts outside of the text. My own existence is rife with a similar but unique set of conflicts that being queer in a heteronormative world entails.

As such, the work of solidifying a space for queer-assemblage (re)visions of traumatic "coming-out" narrative is crucial. It is necessary for identifying new terrains wherein one might attempt to locate new meaning through the fictionalization of one's own being. We writers embark toward a discovery of ourselves through the negotiation and reimagining of ourselves through our relationship with "coming-out" trauma. In apprehending and communicating our wounds, both visible and invisible, with creative, metaphoric expression, there is potential for appropriately attending to and nurturing the specific complexities and nuances of queer subjectivity. In this terrain, it is possible to 
achieve new mappings of being for both the human and unhuman, thus allowing equitable descriptions of individual and collective experiences of queer individuals to emerge and exist in a free play that assists our efforts in procuring some new futurity. As unhumans, we become vulnerable yet again in this act, but under our own terms. We toil and play with our anguish, and we are heard. 
CHAPTER II

\section{(RE)COMBOBULATOR}

I was supposed to meet my younger brother, John, in the parking lot, but he tells me the whole family is there, already inside the theater, and it's raining and we speak briefly about what film we want to see. I hadn't decided yet, but John is rambling on about some high-budget, action-esque crapbuster. I can't stop thinking about how upset I am that he expects me to share in his excitement.

I turn around and he is gone.

The driver's side door of my car is open, and when I get there, John's trying to force his foot, which is larger than mine, into my Vibram Fivefingers - which are like shoes, but more like gloves for your feet. Somewhere, there was an appeal when I made the purchase. I explain to John that the shoes are tightly fitted to the form of my foot, not his, that they'll never fit and he should fucking take them off. When he does, I

immediately examine the soles for any damage. All five of the toes are ripped out and the sides are split. "You're fucking paying for these," I say. "They were a hundred goddamn dollars." John and I head back toward the theater, and I'm trying to figure out why he's acting like such an idiot.

Once we get inside, I take stock of the surroundings. The lobby area reminds me of an oversized food court, though its style is a mock-up of the old 1930's theaters, but with a very eclectic, pretentious twist. The bannisters on the stairway to the balcony 
seating are made of fiber-optics lit with cool-white light, something like fluorescent ice, and the floors are marble and white, the rugs are black, and I see plump, dark oval vases with bamboo sprouting up out of them. Lots of black and white, which doesn't fit my personality at all. The attending staff is made up entirely of hipsters wearing large-framed black glasses. They've got short haircuts, ratty bangs, and they're serving people at the concessions with smug expressions. Furious brown hues dapple the walls and pale flooring, the splotches also coating the halls that lead to the theaters. They're just kind of there, out of place, intrusive.

I see my mom and dad getting concessions. My mother has a tray with coleslaw, potato salad, and chips, but she's going to get something else. When she returns, a bright, fluffy yellow cupcake nests in the center of it all. I'm very confused. Not only in her selection, but the availability of it.

My older brother Jack and his wife, Sabrina, are heading my way. Sabrina's bitching about the service, and Jack is attempting to console her with a remark that he probably thinks explains the situation, but clearly it only fuels her incendiary state.

This is all subtly apparent to me, because I don't actually hear what he says, only see him whisper under his breath, and then Sabrina's eyes dart away from him to study some mundane detail not worth her attention but better than having to listen. I take note of Jack's reddening face and move on, ignoring my parents and looking around the lobby, which as I stated, is large.

I notice that John still follows me, and I find this to be a nuisance because I don't know what he might do next. I find an alcove with a sign that reads "Vibram," and, very anxious to replace mine, I quickly realize that this is likely a vendor, not the actual 
company, so I may be unable to get help here. When we walk inside, I find their selection to be extremely limited, and I'm very disappointed by this, despite my own aforementioned caution. I examine the shoes they do have with futility, dropping them back down on the shelf in disgust. An associate comes to assist me, and after I explain what happened to my shoes, he assures me that he can help, just as soon as I get fitted. He leads me to a separate room. Immediately upon entering, I regret my decision. My coworker Josh and his girlfriend Toni, who is rather large, are both in this room, and she is completely naked and propped up onto a table with her knees in the air as though she is giving birth. Josh asks me if I am getting new shoes too. I dart my head to the right, where there is another fat, naked woman with crooked eyes and drool quickly running out of her mouth and she is just sitting there staring at the ceiling. "No," I say, and leave as quickly as I can.

The machine whirs to a stop and I feel myself gliding from my pronate position to face the Doctor, his smile revealing gray teeth as he makes more than one adjustment to his silver glasses.

"Bryant, how are you? Do you feel there was some success this time?"

"No, not at all, doctor," I shake, trying to catch my breath. A bead of sweat drops from the tip of my nose. "The items were all familiar, but the space ... vague-it was all somehow far more personal than I expected."

"The Re-Combobulator can have that effect in the first couple months of use," the Doctor admits. He examines the data on his glass tablet. Images of my "episode" flash in a replay across its surface, but there are smaller screens next to the episode which replay what was documented about my body during the episode, and on these screens I am 
thrashing and howling in my restraints. The doctor quickly swipes these screens away, briefly making eye contact with me.

"Mother always makes an appearance around month two," he continues, "but the large women in this particular session are quite interesting to me. Perhaps this is a gendered manifestation of your misfortunes with capitalism. Quite misogynous, I must say. Overall, I'd say there's some success here, but we haven't even begun to scratch the surface."

The Doctor tightens some of the Velcro straps that have come loose with a firm yank. Clinicians scurry about the room, making adjustments. The white room hurts my eyes. Its space reaches so far that I have not been able to find any walls, yet I cannot shake the feeling of closing in. My wrist and shin bones ache. The Doctor and his assistants put rubbing alcohol on my raw, blemished skin.

"You'll have to wait until after the day's work for fresh bandages," an assistant advises.

"The male psyche resists being penetrated," the Doctor cuts in, pressing buttons, sauntering back and forth between work stations. "It's necessary to continue forward and push through these boundaries. We must remove misogyny from all of mankind! Let's get started again."

A profound growling whir grows from some belly deep below us. The large white room vibrates and instruments rattle and threaten to plummet from their resting places onto the floor. The Re-Combobulator isn't in this room-it's much too large for that. I've been told it's the size of Manhattan. I've been told that it lives far beneath this facility, underground. I've been told it takes a crew of one hundred thousand doctors and 
one million misogynists to keep it satisfied. The Doctor tells me my deepest, most powerful misogynies must be confronted before they can be extracted. He has told me that the Re-Combobulator is always hungry. I must help feed the Re-Combobulator and help extract misogyny from all of Mankind. I can help them solve this mystery, or I can go back to my cell and remain a delinquent forever. This is what the Doctor told me before they took me from my cell and brought me to be strapped into this contraption. The Doctor gives me some bitter, carbonated water before starting the machine back up with the press of a button.

"It's time to get fizzy," he screams over the whir of the Re-Combobulator, thrusting down onto a silver lever with all his might. A visor covers my eyes and electricblue bolts rip through my brain.

There was Richard, peering in wide-eyed. "Where's the luggage? Are you not ready to go?" he asks.

"I thought you said the flight was tomorrow morning," I protest.

"Don't be ridiculous, Bryant! I might have said that, hypothetically, but I meant something entirely different. We're leaving now!"

“I haven’t packed yet," I admit. “I haven’t even showered today.” Richard stares at me, and I feel it's necessary to concede to his urgency. 'Yes, I simply wasn't thinking! We leave now! My jacket. ..."

I pull the coat from the hanger in one motion on my way out the door. Richard has a taxi waiting for us, and we make JFK airport in no-time, and our flight—-first classpromises to not be too lengthy. I scarf down lobster and scallop surf ' $n$ turfs with such 
speed until I need to unzip my fly. I can't be bothered with the crunchy bits. Richard wakes up from a short nap and sees me slurping on my greasy fingers.

"A fine idea, Bryant! We won't have time to eat later." He orders seven rolls of sushi and tears into the kaleidoscope of deliciousness as furiously as I strangely recall him delivering speeches, halting only to once again acknowledge my slurping with, "That's the only way to do it, Bryant," and I agree, although I struggle with so many crustaceans clamoring for room in my gut. I realize the decision to eat so much will have us both bloated and farting for the remainder of the flight.

"Ah, that was a honker!" Richard shouts, having released a riotous waft. The female passengers are quite distressed by our natural emissions, and it isn't too long before a stewardess approaches us.

"Excuse me, sirs, but could you possibly relieve yourselves in the restroom?" She is a frumpy-looking thing, with flushed cheeks and hungry eyes. She doesn't seem nice.

“I apologize," Richard says. "I didn't realize it was expected of me to incarcerate myself inside the restroom every time I feel the urge to break wind."

"It's just that-"

"Nonsense. I'm sure it's more to do with patent stupidity," he says, waving his hand, falling silent, and then relinquishing the anger inside him that was building from the moment she'd uttered the first syllable, as incoherent as it may have been.

"You have absolutely no idea what flatulence is, do you?" he spits, gesticulating wildly. "You see, from my perspective, every time you open that mouth of yours, a high crime is being committed in that such abominable vocalizations are permitted to escape that hole in your head and ... waft in the direction of my body, my auditory ranges. How 
dare you be so irresponsible! I can feel my neurons committing mass suicide as we speak. You're a complete moron, o vacuous wench, and I'm afraid I can't deal with this in such a linguistically compromising manner. You're certainly not an equivalent, by any standards.”

Richard stands in his seat and turns, unbuckles his brown slacks and lets them drop to his ankles.

Excellent data-the Doctor intrudes-but let's see, Bryant, if we can't push further along and isolate the pure moment of misogyny.

"Let me show you ... perhaps you will understand this language better, judging from the absolutely daft expression I see there. Yes." Richard bends over and pulls apart his cheeks with a hard, white-knuckled grip, his face beet-red and strained. He unleashes a firm blast, astonishingly harsh. The first-class passengers gasp and my own eyes surely could have rolled from their sockets were it not for my optic nerves and ocular musculature. The stewardess' face is peppered with sweat, hair and crust. For a moment, I fancy the fabric of space-time rupturing, and in this vision the bowels of suitably wretched fecal dimensions eats the woman hungrily up from head to toe, like lips slurping up stray noodles and legs. Behind us, the slick leather of fellow male passengers' seats become more audible, and I hear fierce clapping and laughter.

We are all applauding you up here as well, Bryant. This is good work. The ReCombobulator is giving us excellent feedback on this work. Let's thrust on.

"Bravo, a show well-done, our Dear Richard," the men applaud. I turn to see, in the crowd, a richly dressed businessman bearing a meticulously trimmed goatee. The puffing away on his cigar quickens as he runs a comb through his jet-black hair parted 
down the middle. He slathers a streak of rich pomade across his squared crown, slicking it back with the tines of the comb, a twinkle of familiarity and kinship in his eyes. I see Richard gazing at this man with a sincere, deep adoration as they join their hands with a clap and shake sturdy.

“Pierson, you devil! Ha!" Richard then turns to me, very excited. "One of our financiers for the Re-Combobulator project I am unveiling to you. Bryant, this is Hamilton Pierson, esteemed academic, businessman, and author." Pierson looks like human pomade in a fancy suit, and Richard's comment results in the man tightening his necktie while taking a fervent, proud sniff that tilts his head back. I feel the session beginning to take on stranger quality.

\section{I had the same thought, Bryant, but don't worry. The Re-Combobulator is strong enough to handle any misogyny.}

Pierson takes my hand, his white silk glove gripping my flesh curiously strong.

"Bryant is our Press, Mr. Pierson," Richard says, refastening his belt buckle.

"Ah, a journalist," the businessman muses, stroking his bearded chin. "You've quite a task on your hand there, as Richard's project is nothing short of the great wet dream I prophesied in my last discourse on Future Academe. I sure hope your publisher is aware that one article will not be sufficient."

“I'm, not sure I understand," I reply, cocking my head. The two men chuckle.

Pierson takes a puff, then continues.

"What I mean to say is . . I think you'll find it all to be . . quite overpowering." Richard snickers, but the businessman laughs loudly, each "ha" separated very distinctly. It is: HA. HA. HAAA! 
I myself am not feeling so well. It seems as though the Re-Combobulator might be responsible for most of this. My cheeks grow hot as a dull, sickening weight fills my guts.

"Bryant, are you ill?"

"I think it was the shellfish," I moan, and Richard clasps his hand over my mouth.

“No, you mustn't! We've only a few minutes before landing, and there will be no time for later sustenance." I fight to remove his hand. I can't breathe because the ReCombobulator wants to corrupt even the air in my lungs.

\section{We are resetting, Bryant. The Re-Combobulator seems to have gained all it can from} this. Initializing in $3 \ldots 2 \ldots 1$

There used to be a house on the hill next to my grandfather's shop. Now it's gone. The smell of the shop and the trees is powerful. I am riding in a bouncy truck, turning along Futrel Rd., a path I recognize but I can't see the white house around the curve I grew up in. Grass has grown over the road. It is so bright and green. I see Leah's house on the right is a pile of ashes. She was a dear friend. I don't know what has happened to her. The vehicle pulls up to the white house but I don't get out. Richard asks if I would like to see his dad Sherman's new house. We are there, the light and grass is colored cooler, and his mother Robyn comes out to greet us. Her eyeglasses are bigger than I remember, her eyes smaller, and when I hug her she slinks away. Her hair is stringy and sticks to me, but she gets away. We go inside and breakfast has been prepared, but only for Richard. I tell him that his new haircut makes him look very young. His hair is longer and lying flat instead of standing on end like it does when it's short. The kitchen counters are the color of pine, but the texture isn't as refined as I would expect. "These are nice," I 
say.

“Sherman spares no expense," Robyn answers, still sitting down, her bumblebee glasses magnifying her eyes, but a white glare obscures much of them. I think that she seems alone, but a comfortable-ness which exists in that alone-ness is pronounced and terrifying to me. The looming silver appliances tower around me and what I think is a refrigerator is an oven. The oven has two doors that open instead of one. The oven has eight steel grates placed over the burners. The real refrigerator is made of copper and sits with plenty of space to walk around it because of the doors on all its sides. The metal appliances shimmer with glee but the kitchen cabinets are dull and neglected, like powder out of reach in tiny corners. Richard takes me around the corner, and there is a second kitchen, but the appliances are much older. "A second kitchen?” I ask.

"Yeah," Richard says.

"Washer and dryer in here too," I point out. I notice there are two sets. We turn around another corner, and there is a third dryer. “There's another one here," I say. Richard doesn't see it bounce with joy after I acknowledge its existence. We are going upstairs, but I am looking at the house from the outside, so I can't see what that looks like.

I'm on a city bus in a small town, but there are skyscrapers everywhere. The bus is crammed and I'm standing up, and passengers are sweating and groaning. I'm going to be late, I know it. "Man, you need to andele!" a mustached man urges, and I feel a burst of vitality that is encouraging. The bus, trapped at a jammed intersection, drives onto the curb and goes around the intersection. I'm in a store now and the female customer ahead of me orders a cupcake. The blonde, female employee is wearing a brown apron. The 
fluffy, sunshiny cupcake nests on the counter. A pillar of white filling slides from some unknown location above me, down into its innards. The cupcake swells, and a plop of chocolate covers the top, then a dusting of red, blue, and white sprinkles rains down. The cupcake is done and it's perfect. The American Dream . . . it's complete, crisp, fragrantglittering with glory. The customer goes through a door and into a back room. It's my turn. The filling descends into my cupcake, but it bursts, a spattering of white goo slopping across my chest. I depress a lever to try again, but each time the cupcake bursts with a loud pop and deflates like a balloon. On the fourth try, the filling shoots from the side.

"I'll just take this one," I say.

“That'll be 15.93," the girl says. I'm disgusted. I shouldn't have to pay for all of them.

"If I'd known I would have to pay for these fuckups, I would have acted on the first one."

I go into the back room with my cupcake. There are only walls and two doors, but odd menacing specks are zipping past me. The wasps land all over the cupcake and start eating it. A swarm of the greedy bastards pours in from the ceiling. I throw the thing at them, noticing that their angry faces appear to be distorted caricatures of the nation's dead Founding Fathers. When I exit through the same door I entered, a tall, bald man with hollow eye sockets and a bloody apron is standing there. I walk past the Doctor. I am curious as to whether the Re-Combobulator thrives on more than misogyny. I am curious as to whether it is vulnerable like me. I will try and penetrate the ReCombobulator, just a tad, just a tiny bit. 
Careful now, Bryant, things are getting a little rickety up here, but we are still within acceptable ranges. We were all excited for what was coming next, but this doesn't seem to fit the Re-Combobulator's appetite, not after all those tasty treats.

I am not sure if this has all been $m e$, or if the Re-Combobulator is behind all of this. The Re-Combobulator seems like a huge and terrible force that will turn my brain into pudding and crush my bones into powder. I think the Re-Combobulator is trying to make me a certain way to feed itself, a way that I probably was before, but not as badly as I am becoming. I am unsure if the Re-Combobulator could ever help anyone, let alone all of mankind. Some part of me wants to feel sorry for the Re-Combobulator. I wonder if it sits all alone underground and never gets to meet any of us who attend to it, those of us who feed it what the Doctor says is "such nutritious misogynies."

Initializing in $3 \ldots 2 \ldots 1 \ldots$

The remainder of the flight was uneventful. Richard and I departed from the plane to find the airport terminal relatively congested with people due to flight delays. Richard appeared upset by this - I noticed, and I seem to recall him mentioning something about there being "far too many vaginas in the vicinity" when we made our way to baggage. His hands quivered when he said this, and as he rolled back the plaid sleeve of his left arm to view the time, an abundance of shouting burst from one of the baggage claims at the far end of the room.

"Feel the power of Christ! Submit to the word of God! Live in the light of His Truth!" 
A pastor with gold rings and a hefty quartz watch that glinted strangely in the fluorescent light sat perched atop an alligator-skin suitcase. His open palm landed firmly on the pages of his Bible with a slap, his audience a sparse crowd.

"Oh, dear me," Richard sighed. "I'm afraid I must resolve this matter, Bryant."

“But Richard, won't we be late?" I started. Richard didn't answer, simply led the way with his ravenous, gangly smile. He bolted towards the crowd, speeding straight to the pastor. I watched as Richard leapt through the air, tucked his knees and twirled just enough so that his rear shoved the man aside. The pastor's flesh smacked against the polished floor, Richard landing smoothly on the man's suitcase. He straightened his jacket and cleared his throat.

"I'm afraid what this man has just told you was not what he originally intended. What he meant to say, however, was something more akin to this: "I must confess ... that while the following may indeed seem like well-collected truths, and that you will find yourselves sufficiently contented in that you will potentially stand here for the entirety of my very breath, drooling over the rampant, unnecessary, egotistical sputtering of someone hopelessly brainwashed since birth by the very same ilk, all I have to say is, in fact, mere conjurings of a people who indelibly combined ancient stories and pseudohistories with extracurricular activities, embedding within their holy texts the traditions and symbols of that particular bullshit, resulting in a heritage that when caught like flame in the populace, mutated and grew into a network of collectives throughout time, perpetuating as hot embers and ashes we continue to ingest - the strife, the suffering, the suppression of cognitive thought abounding, the visage of the solar and lunar deities, surreptitiously elucidating the call for newer, stricter proliferations of lies in order to 
facilitate further and more comprehensive control over the masses, to subjugate them with greater obfuscation, and it is this collection of extraneous historicity that has somehow surpassed its own disinformative tendencies and today managed to encapsulate generations of majority in utter stupidity."

The pastor regained his footing and rushed after Richard, who promptly reached into his slack as though he were about to fondle himself, but instead drew out a fossilized dinosaur bone, striking the man on the forehead. Gasps erupted from the crowd, some individuals staggering as they shifted with fright, one woman struck her own forehead with the back of her hand and swooned to the floor, but no one intervened. Richard, a maddened grin on his blood-spattered face, held the painted fossil high above his head. The pastor lay on the floor, down for the count by the sickening blow from Richard's Triassic bludgeoning.

"My friends ... this is evidence. It is real, it is permanent, and it is absolute." Oh, Bryant, this is most exciting. This is juicy data. It has been apparent to us for some time, the divine nature of misogyny. What other healing juices are coursing through this meaty misogyny, this rich little bit?

Richard continued.

"Therefore, it must be declared in all honesty, that by passively standing here, you are, in fact, positively subjecting yourselves to highly evolved anti-intellectual whoredoms — immensely insufferable—depreciating intelligence quotients, and though the urge may be too great, you must resist succumbing to a comfortable state of oral addiction. You must do the opposite. Discover a perpetually confounded state of 
apathetic cocksucking, bewilder yourselves with new information, perplexing discoveries and infinite possibilities, and persist with relative, logical questioning!"

Richard ripped open the front of his trousers, presenting his throbbing, uncircumcised member. Several people gasped in awe. Others struggled to get on their knees in front of him in order to be the first to get their mouth around it.

"Kill yourselves," Richard screamed, as two women and one man began furiously suckling on him, "Rid the world of your revolting nuisance! But before you do so, read something bloody scientific. Something factual. Read a paper on the state of neutrinos, perhaps. A dissertation on the evolution of mayflies, even. For fuck's sake, read a cookbook! But don't stand here and continue to listen to men babble about the invisible and the un-knowable with no compunction for rational thought! If you'd bother to study the subject, you'd find that there's nothing wrong with carbon and sedimentary dating techniques!" Richard tossed the fossil to one of the bystanders and jerked his engorged penis from the mouth of an admirer with a pop, stepping down from his perch and revealing that his pubic hair had been ripped out in patches. My eyes searched the faces of those who were giving Richard his due adoration, finding that his hairs remained fastened between their tightly clenched teeth, their eyes bloodshot like rabid animals. Yes, this is so juicy and slippery, Bryant. This is nice, nice. The Re-Combobulator is roaring with excitement. Our only concern, however, is that there was a male among those suckling wenches. The Re-Combobulator requires that you limit the misogynies to the appropriate physique, please.

“Five minutes lost already, Bryant. This won't do. Our taxi has probably already settled for another fare." 
"Surely not," I said, "You are Richard, after all." Richard looked at me as though I'd challenged him, and for a moment a surge of sheer, mortifying panic turned me to stone. Richard stuffed his fist into a pocket and upon withdrawing it, shoved a pristinely formed yellow cupcake decorated with American-flag icing into his mouth.

"You're right!!" he spat, the red, white, and blue icing muddied and smeared across his glistening lips, and this made me relax as he continued. "Time isn't important. Einstein was a farce of nature! A jest of modern scientific proclivity. He didn't even finish his own field equations! Have you seen this?"

"I have heard that, yes."

"But have you seen them?" Richard hissed, coming close. Fire flickered in his eyes, and I could smell the sweetness of the cupcake turning bitter on his breath.

"Well ... no," I admitted, scraping my moist, sticky palms together. "Of course I haven't physically seen them."

"Ah,” Richard said, jolting a back. Perhaps I had confirmed for Richard, the nature of a particular conjecture tickling his brain. Perhaps it was something that would turn out to be opportunistic for him but detestable for me. Perhaps I was paranoid, and far more mistaken than I would ever admit.

Perhaps a slight detour, Bryant? A swift romp? Would a modest quickie—a slick 'n slip, or slide to the left-would that entice some new insights, some succulent sensations? Would they, for just a bit?

The Re-Combobulator's appetite is beyond control, and I wonder if it can be recombobulated. I promise the Doctor that exquisite misogynies lie ahead.

Re-inititalizing in $3 \ldots 2 \ldots 1 \ldots$ 
There I am, just chilling on this grayish-green couch in the library. I'm in my Dockers and gray, collared business shirt that's stippled with white buttons, and this brown-haired chick is sitting rather anxiously on an identical couch positioned at a right angle to mine. She's thin, pressing her palms against the cushion as though she's hungry, or about to push off, or waiting for something, or not sure what to do with herself. She's just there, dressed in a skimpy spaghetti-string sherbert-colored dress with fusia and lemony hues faded into its square patterning, though it's all done tastefully and doesn't look like a tie-dye shirt, her skin a burnished, wonderful shade of toffee and her round shoulders and cheeks delicately freckled. She's in possession of very supple C-cups, and I also notice the yellow flip flops and candy-apple-red toenails to match her lips. A straight line just above her eyebrows chops through her brown bangs, the rest of her hair falling in shimmers down her back, and those dark eyes of hers are reflecting the yellow light of the studio lamps that are positioned at the corners of our sofas when she looks in my direction.

I realize that she is about to speak, or maybe she is just craning her head and pouting because she thinks I should photograph her. I generously donate about half of my full attention.

"So ... you seem pretty smart," she says, swaying a bit, and I nod my head to acknowledge the obvious, and then I choose an even more redundant route, replying, "Yes ... I am."

My large, over-stuffed pack is more than enough to prove it. I gently tap the gray, multi-layered bag occupying the cushion next to me, smiling at the girl with a slightly playful, slightly challenging note on my face. This girl is timid, or is looking that way as 
an affront, despite her excessively "out-of-your-league" adornments, but regardless, I determine from her statement that she will likely be very turned on if I begin to unzip the pack and flip through one of my slick, adequately filled notebooks.

I do so, and my suspicions are confirmed, as the girl does in fact begin squirming on the sofa with a slight look of distress on her face, perhaps shock at the sudden and immense arousal she is experiencing. She crosses her legs and bites at her bottom lip, her eyes begging me to just turn another page, but I don't. I simply regard her once more with a quick glance up from my work, and then I return my study to the lines of the first paragraph of notes I so graciously took in my previous course, Gynecology.

\section{An excellent subject to study, Bryant. We are well-versed in this topic as well. This}

\section{misogyny tantalizes us with its oozing forthcomingness.}

I note a continuing frustration by the increased movement of the girl's petite frame, and I snicker to myself, withdrawing a gleaming silver ballpoint Horchow. The calculated click of my thumb depressing the plunger draws a quick fretful gasp from the girl's frail lungs, and her eyes flutter like a hummingbird. I sense the beat of her heart must be traveling just as terrifically, and with my excellent vision I can see small beads of sweat beginning to form on her brow. On the verge of tears, the expansive depth of her dark irises are fill with the intense, lurid green of my own, my charisma, and as we lock our gazes together, fixated, I communicate through to her that I am a man of passionate professionalism, and this seems to only make her senses more fraught with unbridled, uncontrollable desire for some generous offering, some simplistic yet articulate taste of my candor, as though I am renowned with the reputation of delivering every syllable with some profound, ecclesiastical measure. 
The sweat beading on her forehead has been joined by more on the upper lip, and the cheeks have become flushed and hot and bothered. I am reticent to note that this specimen is too close to push further. Any typical gentleman with skilled execution of prowess would be able to achieve such a thing without spoiling the moment.

Salty perspiration trickles into the crevices of her supple cleavage, which I acknowledge once more with a quick rap of my head and musing, a slight hum, and then I find myself glancing at the gold-leaf foliage-embossed square tiles of the ceiling, of which I am not a fan. The girl's eyes have gone up with mine, and when I lower mine, she lowers hers. I note that the creamy ivory carpeting and pretentious, hour-glass lampshades are much more interesting, and I let her know that I am just barely considering her presence now with my silent, critical evaluation of their slightly interesting idiosyncrasies, but just a little longer and the girl will pass out, so I decide to ease her most pleasureful suffering.

"I'll just make a quick notation about some of this right here," I calmly say, staring at her. I envision that as I do so, a tiny ribbon of light flashes across my lenses.

Melting from the couch with a squeal, the girl thrashes to the floor in throes of explosive spasmodic joy as though the upholstery were greased sheet metal. I uncross my legs and sit up from my casual position with haste, careful to not miss out on capturing the exquisite details. She presses against the sofa and floor with her extremities and pulses as though she is repeatedly attempting to form a gymnastic bridge, caramel thighs jiggling like someone has surreptitiously hidden a powerful oscillator under the seat of the cushion. I am compelled to put the notebook away into the confines of my pack, and I take the time to properly select a spot in the pack that is already filled so tightly that the 
notebook cannot possibly fit, but I manage to stuff it in — gingerly, not forcefully — and without damaging the pages, and as the girl finishes up with a series of high-pitched moans I heave a great sigh of relief as I have managed to secure the zipper without tearing it from the seam of the stitching. I look back to the girl and smear a stray drop of fluid that had formed from my own frustration on my left temple, and I offer a very genuine grin of slight approval.

Bryant. You promised us exquisite misogynies, but this is very slight. We will assume some command and insert some stimulating material from our memory banks. The ReCombobulator is salivating rather heavily, rather messily.

Suddenly, the door at the far end of the lounge bursts open and a tall thin woman with peachy skin, ruby red lips, heavy mascara, and shoulder-length curly red and copper locks comes strutting in like she's trotting a catwalk at a Victoria's Secret fashion show. An intrusive thumping burdens my ears. Trance EDM thuds, electrifies and pops-real whoppers I tell you, coming in at half second intervals, inexplicably summoned to accompany her gait. As the woman grabs my face and leans in to tell my body, 'I'm a voracious cunt and I've got the high heels to prove it!" I find that I cannot determine which part of her bears more strength.

This new woman's attire, at a first glance, seems very condescending in its authoritative presentation: a tightly fit white corset covered by a black vest, all somewhat concealed beneath a red and black checkered overcoat. My cheek stings and glasses knock as she strikes with the white vinyl gloves, and after gently wiping my face, as if to apologize, the woman ragefully tears the gloves from her hands and casts them to the floor along with her coat, pouncing over the garments with clobbering, knee-high struts. 
Her heavily-laced matching milk-white vinyl boots clobber the tiles, netted black petticoat round her waist dotted with red hearts and flapping wildly like a flimsy dryer sheet or curtain as she assumes various, extraneous poses of empowerment. However, it's the red business tie that hangs from her neck, thrown to one side that my intellect is unable to consider as having merit. The woman appears dismayed by my lack of interest, trouncing forward once more, forcing me back into the couch with one of her long, spindly, lace-covered legs, her foot pressed firmly against my breastbone and the high stiletto heel digging in. I don't concede by any measure, and even when she draws a black leather cattle prod from the sanctity of her boot and lifts my chin with it, I still have a smirk on my face.

"I'll show you how to work a girl," she growls, her blue eyes hot with a mixture of determination and cocaine, I imagine, and I respond with a fervent "harrumph," which prompts her to push off my chest, the heel of her shoe creating quite the sting, but I am rather anxious to see this demonstration. She throws the prod and begins to dance, smoothly gliding in place and lifting her curls rather theatrically, to which I am unimpressed, but she quickly picks up the pace and moves beyond the borders of cliché nightclub sensuality, slinging her athletic body around, squatting and thrusting her legs high like there's invisible strings attached to her joints. She sees that while I am not completely disinterested, I am still unmoved to a degree, and that I have, in fact, begun edging nearer to the pack so that I may cop a feel alongside the stylish netted exterior of its flank, my eyes fixated on the musculature of her outer thigh. She stops and lumbers like an angered rhino or unbalanced mannequin, of which I am not sure, and to my distress she rips the pack from the cushion as though it possesses no weight at all. I am in 
both a state of extreme shock and arcane gratification, as I don't immediately decipher with my normal reasoning prowess the governing factors behind this pleasureassociation, that being her effortless possession and extraction of my pack. I am somewhat confused. It seems that more observation and experience will provide the most lucid, pronounced interpretation to me.

\section{Bryant, there seems to be a fine line here, but I am confident you will not lead us all astray.}

The woman slams the pack onto my genitals and stomach and I am in great pain, but so impressed with the speed and ease of her movement that my contortions are clearly not illustrating any discomfort. She very carefully begins to stroke the very-filled pack and pluck at the multitude of zippers with her glossy onyx nails. The torturous teasing is mimicked through pinches in my flesh, and the woman doesn't relent, is emboldened by my reaction and saddles the pack. She lurches back and forth as though it is a mechanical bull, the increased weight further suffocating my sultry erection, while the other girl has returned to her seated position of confidence-bankrupt dissatisfaction, as her repressions prevent her from disseminating the display of absolute divine intervention taking place: I realize that this woman's aim is to destroy the restrictions placed upon my novice-like consciousness.

This is her perspective, and while I don't appreciate the attitude, her energy and bolstered efforts overpower my meager complaint. I am sweating profusely now and grinding myself into the crushing weight of the pack. To both my great surprise and wonder, the woman begins to tear the Velcro tabs open with wild gestures, screeching like a bird of prey when she does so. This sound, coupled with her rocking aboard the heavy 
pack, makes the experience far too novel for me to decipher, so the urgency of my member takes over. My silver-rimmed spectacles are crooked, my hair is disheveled, but I am filled with a delight I haven't experienced since childhood, and just before I am about to explode with joy she leaps up from her seat of power and throws the pack across the room, traipsing a few feet in front of me to stand motionless.

"What the fuck!?" I demand, throwing my arms wide. I straighten my glasses and tear the black Ralph Lauren necktie from my collar, ready to take her. My armpits are sticky and my Calvin Klein briefs cling to my ass and thighs. The woman strikes a challenging pose and keeps me at bay with one hand, palm facing me, while the other rests on her hip. One heel is slightly raised, the other planted like a goddamn sycamore. She says nothing and with a swift flourish tears the petticoat from her waist like it is wrapping paper, and I see that she wears no panties.

\section{A hard woman, Bryant. We are all anxious to see what happens next.}

The woman squats onto the floor and begins prodding at herself with a look of extreme arrogance and contempt. I intuit that she believes I either cannot possibly satisfy her, or that I am barred from participation for my previous actions. I cannot believe the pace at which the woman begins to stroke herself and I am worried that she must be causing injury, but the moans, open mouth and clenched eyes, they tell me otherwise. Bryant. This woman is something else. This woman is fierce. This woman might be difficult to make a misogyny about. What have you gotten yourself into here? This wasn't our idea when we introduced her Not our idea at all.

The woman bounces and begins to chant, "Her finest stroke, watch her stroke," with a commanding tone, the rapping, musical thump that accompanied her entrance still 
drifting about her countenance, flooding my ears from an unnamed origin. A blue jolt rocks my brain, and then I notice as I stand up that there are fifteen-inch sub woofers placed all about the room and around our feet, the coverings gone so that the yellow, foaming, caking cones pulse and drive the woman's every move. She moans and thrusts herself up and down so fervently that I consider there must be an invisible phallus $\boldsymbol{Y E S \text { , }}$ BRYANT, FINALLY YOU ARE BRINGING US BACK somewhere, but I realize when I walk in front of her that the force her hand employs gyrates her entire body around like a rabid, frothing sock puppet. Red curls are flying about her head like long ribbons fastened to a balloon, and there are large pieces of silver glitter, and the studio light, and blue and yellow strobes pouring into the room, and I can no longer handle what is occurring, my Ego may never properly feed the Re-Combobulator misogyny, I may be stuck with misogyny forever and the Re-Combobulator will invade and extract everything from who I am and the subconscious along with it, and this programmatical Freudian cluster-fuck will insist on playing out for all eternity and none of the doctors or other misogynists will ever be able to stop it, and I begin laughing hysterically at the diorama, pointing at the woman who is still furiously at work on herself, as well as the other girl, who doesn't seem to understand my sudden change of demeanor, much less what the fuck is happening or what she is doing to herself.

Bryant, you must secure the pack. It gives you power. At this juncture, it surely contains the only misogyny left. If you cannot, we'll cut our losses and re-initialize. Bryant, can you hear us?

I stagger to the couch and see the pack against the wall in a disheveled state, broken and ripped and open so that the books, binders, and notepads have all stained the 
carpet. A profound sense of horror and pleasure assaults me like some pungent fume, and my racing heart seems incapable of pumping enough blood into my genitals.

The woman has begun laughing a mad, maniacal laughter that begins as a scream, her face appearing as though it might rip in half at the corners of her mouth, and my only hope is that this will all subside, but as the intensity of her laughter grows, so too does her masturbating and moaning, somehow, and then I fall onto my back and I see her from the floor, and she crouches on her hands and knees now, releasing a porcine howl as she begins squirting towards the back of the room. She sprays and sprays and slams her palms down onto the floor and time itself seems to stop, and the entire room is rocked with a vibration that shatters the ornate vases and light bulbs and sends sparks flying, paint chips cracking and splitting from the walls, tiles from the ceiling, the concussion rippling through the cupcakes with spurts of thick viscous icing and it all sticks to our hair and clothing, and the sound of the woman's scream, her penultimate pleasure and consternation, coupled with the thud of the speakers as they burst, all propel her fluids and the frosty cupcake innards across every available trajectory in the room like splotches of silly string. I look at the floor, and from out of the woman's vagina has fallen a dissertation on female masturbation, tightly bound in red, white, and blue ribbon. A plump yellow cupcake with an egregious amount of frosting is emblazoned on the cover, and I notice the woman eating one just like it. 


\section{CHAPTER III}

\section{DINNER PARTY}

just as Caldwell promised, when approaching the slithering road that led to the mansion, strange men cloaked concealing garbs greet, faces so tightly bound I do not see them and they were men, due-stature, manner of complacency, though possible, in my recollection, that I am mistaken. the black wrappings made all a mystery but for a silver band which ran across the middle of their faces, from temple to temple. silver-silver, though this piece of metal sockets for shrouded eyes, small rectangles cut the metal, no glimmer of life shined within, I want to say, behind those eyes, tight scarved wrapcovered mouths, these figures grinned, but I couldn't be sure. another set steps from the black carriage that would have transported me to the Admiral's estate, this figure's cloak aptly adorned golden borders, masks bearing a sliver-silver-gold, polished gold, goldgold driver tilting head down, curious, perhaps wondering why silver-silver not yet steps into the carriage.

invitation, please, gold-gold breathed gently, I presented the parchment from inside my overcoat.

Caldwell had, for some time, been in attendance to these strange parties, returning to our estate with an uproarious elation and desire to regale myself, his Duke, as well as the whole serving staff, with tales concerning the Admiral's wondrous delights. 
I initially dismissed the gyrating for misplaced fondness in the Admiral, recent relocations in Caldwell's returns increasingly disheveled states, unsettling, even my own sense of reserved alarm. his most recent ragged ridden ravaged torn clothing stunk of urine fibers feces vomit semen and other materials.

please, enter, goldy-gold gestured. I suddenly found myself pleading with my heart to calm, my stomach to settle. The man took his seat across from me in the carriage, I heard the snap of the reigns, and we began our way. He did not speak for the duration of the journey, which as Caldwell had said, lasted nearly an hour. I tasted sideways and found that the carriage rifted a gentle way in a direction I had not previously noted, and in finding this to be rather hypnotic, the gentle rocking and the blank void enveloping the sheen of the mask gazing back at me, perhaps gazing upon me, as though it were looking directly into my soul and weighing its value, I found myself deciding whether or not I was worthy of the wondrous, and whether or not a swallowing of myself through a cloud of un-impregnable vastness harkened imaginary canary coal mines, songed in and out through fizz, effervescent infernal warning to warding off the familiar.

we have arrived said gold-gold finally, in only moments passed I waited to exit second, taking notice of how the garbed figure slid with ease from his seat to the ground, appearing a small clearing between forests and mists which sprit in spit the full moon-a cast, a silvery sheets fast on the landscape.

the estate nowhere in sight, ahead a trail winding through the field, lights in the distance amongst the trees on a large knoll, it occupies, it sprawls.

up there, gold-gold pointed, giving me a large brass candelabra lighting the three white candlesticks. you are not coming, and the masked man's silent strange feeling 
thinking now, felt anxious - heart held cantankerous yet lofted lightly above, dwelling over and about in going alone.

I am only the ferryman, I nod, taking note of hesitance to answer me, and them, they are the ferrymen too, I said, looking up to silver-silver's mask glinting towards me. I would have smiled, smiled, smiled a placing hand on the man's shoulder. Shoulder smiled, smiled, smiled-shifted, him shivering, realized I had mistaken his importance, when before I had thought him to be a servant of the Admiral.

likely an unwilling servant and this angered me greatly.

mine were never forced as I always asked first, asked again, asked and asked and begged and bargained and they were paid well. I took back my hand, offering a polite bow before turning to leave.

we have heard you are despicable, I and the masked man and the moon called after me. I turned around down and backwards, almost certainly appearing bewildered. will know it when you see yourself tonight I folded away from him in flutters moving up the path and into the forests fanning-fannying, noticing that at my sides the path-legs-running-adjacence sprinting their tramples next to me, next to me others winding windy through the wooded woods by yellow-lit candlelight towards the glow at the center, foresty centered dozens of us, all moving silently in our dark coats hooded and not, none of us speaking, one another with polite nods soon-seen the estate.

I find it taxing to recall the exact details of the mansion in the luminescence that seemed to adorn its very walls and reach out from within it. 
I find the center of the mansion square, three or more floors, its façade reached out, rounded, second floor dropping twelve large pillars, roof down over the entryway, a great white creature climbs out of the earth, untamed and insatiable, its carapace frozen in a bitter, unsatisfied grimace. my blood churns, but I remember the wonderment, just as Caldwell had promised.

Bevergius, I'm afraid you are sorely mistaken! sputters Admiral. fervent hiccups separate his words, slams the drained dribbly mug to the table, foam-slinging clap about its rim flying out and loose gold coins rattle.

what is it about the mistaken argument? protests the exiled royal, Bevergius removing marshmallow shaped hat—cock hat—-to once again comb his greased grimy hair. gamey smells, bloody, strip-scalped and scabbed, scratching for thoughts through the itch, examines himself in a shard of mirror lying on the table.

the dirigible's cabin is in shambles, and there is fucking all around us, following the latest attack. cantankerous displays of flesh and bodies and fluids sailing side to side, laugh to laugh, tear to tear.

parchments and drafting materials were strewn about, occasionally demanding to be shoved into my anus or burnt bluntly by passionate heat.

the airship would list to one side, if it could, and stray barrels long-emptied of sweet mead would roll across the floor, along with iron drinking cups, straight into that hungry chasm!

first, the Admiral remarks, twisting one side of his mustache with the silk of his white glove, and pointing into the air. 
I know we cannot possibly hope to attain victorious dinner-wonder if we engage now. we must resupply. if we do not, then I'm afraid not even men, men-women, womenmen, women-men-women, wo-wo-men-men could satisfy enough to resist the cunning tricksy whoredoms within us.

wonders that not even the most disillusioned and melancholy can resist.

I'd caught a glimpse once, while sneaking through the underbelly of a cavalcade as a young child, looking for scraps fallen from the legendary locomotive feast scouring the land in search of untapped resources and my unpenetrated, young orifices.

at a moment of sheer desperation the youth I was emerged from a trough of excrement beneath the table, ingested, subsumed, transmogrified.

airborne on the fumes of inflated, conquered royalties whose fermentations force me and then he saw them, the most beautiful paintings he'd ever laid eyes on, works of moving life, large goldy-gold in the frames filled with orgies of the finest stock ravaging one another, the apocalypse nigh, couples-trios indiscernible, glass encased in sealed, in the luminous panes, in the shattered beams of sunlight, the prism speaks the breath of holy rainbow, the muffled groans of the powerfully muscled, thin, flabbed, pitter-pattered, doughy, fit, greased and bronzed-wrestled, and healed-dismembered, and ill-well, conquered at the behest of the royal, the gold-golds and the drumming beat-slap of flesh, flesh, and flesh just very faint, daintily pounding, whispering emanations from the great works hoisted and hung, a banner on the walls, a banner to the masses.

Admiral, baritone and wild-eyed as a new horror came to mind, frantic-screaming lest we not forget the twentieth reason! that my good man, says to me and all, finds us 
more esteemed with failure than an ill-prepared chef at one of the Lord's many brunches! yes, the twentieth reason, musing, staring intently upon the putrid portrait of some unidentified man's exposed buttocks as though panacea predicament offers fled into the eyes and purified minds, the man lurched over tearing hair-handfuls from a left cheek. the crew lingering in the dirigible nodded, Bevergius silent. that is, assuming we can get to twenty, the Admiral finished, gripping the goldgolden handle of his saber unrelenting, stroke-stroke strum-thumbing the handle as he pace-paced about, one stroke, to step, two steps, twenty steps stroking the handle to the pace of his golden thumb.

the Admiral speaks in a mysterious, ambiguous fashion I would have yet to decipher many times, but we did, though it was becoming more clear by the hour that no amount of reasoning would lend any aid to beleaguered minds.

they had yet to identify the impetus for the supposed ambush in the dinner-partyimaginary against an unknown enemy, a Lord Feastington, let alone why threats palpable percolated and pierced, their skin, their flesh, the pleasure-anti-pleasure, frenetic, flesh, panic, bliss, exasperate.

of more concern ... a skepticism that he would live through the next night, after having witnessed what happened to his trusted associate, Caldwell, just two days ago on the Girthington Express, as he'd called it, a train of misery barreling down the tracks of oblivion.

the thoughts lingered in my mind like some craving, some diseased appetite for the unknowable. 
we reached the guarded entrance, handing our invitations accordingly to the two cloaked men that Caldwell had promised would be waiting on our way in, a soft melody of strings excited my ears, we were all handed champagne by more cloaked men, which I used to douse the fire in my parched throat. another champagne. another bubble. another muddle.

we're all awaiting the arrival of the Admiral, the man said. he is going to make a toast. I took the glass and grimaced. we were ushered through a long white hallway lined with portraits of individuals I did not recognize, though the style of painting certainly hailed from the renaissance. a deep crimson rug spilled out before us, and I cannot say that anyone who was near me was someone that I recognized from our city, which I found to be strange. another masked man stood in front of the two doors leading into what I assumed was a great room, judging from the architecture I'd witnessed.

when the doors open, his voice boomed, you shall file into the ballroom and wait patiently for the arrival of the Admiral, and when he has arrived, you shall raise your glasses and accept his toast!

shivered in my boots, my face flushed with heat, evidence of this peculiar marriage of fear and excitement in the faces all around me.

the Admiral emerged from the head of the ballroom, wearing a vibrant costume with briefs emerald green and white pen-striped tights, a regal jacket with punctuated shoulders the hue of pale blues and greens, pastel almost, though he'd spared no expense on the fury of sashes, ruffles, golden embroideries, and jeweled adornments that made his true form somewhat of a mystery. his powdered face beamed with anticipation, his eyes enhanced with dark lines, and his yellow lips pouted as he scanned the guests. he wore a 
black wig pulled back tight, braided and wrapped over and over itself, a diamond tiara resting atop it.

drank from our glasses, whisper-fizz crept to nostrils and full orchestra bleatingblaring myself seated in a cushion, swallowed, swallowing the rightmost area of the ballroom playing silver-silver and gold-gold jumping in and out of one another clangingshimmering, servants bearing presents and platters of fine food, and Bervergius and the Admiral dueling.

the table cleared, the chairs repositioned, the ship silent. a lone pedestal placed in which lay a black crystalline rock of sharp facets jutting, its irregular shape.

the Admiral would remove his jacket, would seat and roll up his sleeves, certain confidence breeding about his face through the room. I can hear the sweat spurting from our pores, the drool dribbling down our chins, though with this confidence comes concomitant measure of worry, though just faintly.

Bevergius Baigle, the royal in exile, as it were, removed his ludicrous puff of a hat and quilted tunic, inspected his timepiece before placing it abreast of his heart in its pocket. he motioned for a crewmember to bring him his cosmetic kit, a tiny trunk fashioned from some bronzed metal wreathed in glittering vines of gold and inset jewels. at his delicate touch, it popped open with a slight hiss and he moaned ... a vanity lid into view and gently yellow strobes lit his face. Baigle went about his work, inspecting himself for imperfections.

the Admiral always begins with a different ritual than self-inspection, seeking introspection, setting his collection of varied flasks on the table, some short and fat, others tall and thin, though all of them shaped very differently, made of various 
assortments of colored glass from indigo to pea green to amber, and all filled with mysterious fluids. the Admiral sips from the flasks one by one, taking specific time for each as he recalls powerful memories from their distinct tastes. in some sort of personal rapture, he leans backward, makes gestures to no one and chuckles slightly, in a way unsightly.

is it very fine liqueurs, or thoughts and memories condensed to tit-tat tiny beverages that think, mull and mix murmurs mrs'ing and mistering or mistreressing in mouth, or are there great odds against uttering any likelier explanation just as likely as that but not as likely as soon as I've shoutly-uttered it.

ah yes! chirps the Admiral, holding a shot glass that swirls different consistencies of white fluid. distilled from the jisms of many bedfellows.

I swallow by force in fact swoon-imagining the wonder, the level of skill one must have needs for, for the evaporation process, for the amount of personnel, for the equipment, for the schematics, for the legislation, for the party, for the book-keepers, for the ink for the pens, for the paper, for the arguments, for the fucking, for the crusting, for the moistening, for the lubricating, for the orifices, for the organs, for the tasting and sampling, for the regurgitation and re-sampling, for the pickling, for the failures before success, for the afterglows, for the body, for the body's twilight, for its scars, for its hundred sunsets.

you are fond of your body, I must say, as I must say it was all mustered, voice nearly caught short by the reflex to gag, not a disgust-exhale. not $m y$ body, corrects the Admiral, locks eyes momentarily, reels back with laughter. no no no-no, I've the jisms of most private and prized collections. 
refreshing to have finally shared an understanding. refreshing understanding revulsion. the black coal-like rockfish nugget steals attention, and I traipsing near the Bookkeeper, learn of its origins, and what exactly the two rivals prepared for.

I do not understand.

ah, yes, they will enter a game of anti-wits, the sage warbles bushy, rustly with a scratchy smokey voice and overgrown dirtied hair quivering with each sage-sage syllable. for what reason?

to search for the question to a truth known to us, he says, words coaxing my interest to a peak. to peek a glimpse — a fragment, a small sight, a mere morsel of the voyage as teased voyeur!

the truth is that we are the instruments of enlightenment, says the Admiral, still facing his opponent. he did not turn to look at me when he said it. he was telling everyone. it was a reminder.

tell me about the nugget. it was retrieved from the bowels of the late Lord Infiniton, sage-sage groans, shifting his weight around readjusting his hold on the overgrown wisdom. he opens a book, knowing just where the tale lies.

in the later days of the third month of the three-hundred and seventeenth course of Castle Fecalhorn's Centennial Luncheon, the grand Lord made an outlandish and foolhardy bribe with a rival Baron, professing an intestinal dexterity to finish the remaining thirty-three courses on his own. with great tragedy, and much to the suffering of his people, the Lord was vanquished after having consumed the Crepes of Indifference in a savvy move to bolster his compunction. once his body was successfully severed from 
the throne, an ordeal that claimed the lives of nearly a dozen surgeons, the priesthood insisted on an autopsy to rule out all other causes of death.

what other causes.

it is said in Appendix Z34 that Lord Infiniton made frequent claims that if he were to continue with his loins unabated by at least twenty-one magistrates working in double shifts for more than thirty minutes his heart would surely fail.

in the autopsy several desiccated remains were found underneath the Lord's engorged buttocks, though all seemed well, save for the mysterious nugget in his intestinal tract.

sage-sage closed the book with a snap. we don't know if it was produced from the constant compression and workings of his physiology, or if it was somehow slipped into one of the boars he was fond of consuming whole. we shall never know for sure, though I like to think the former.

what does it do. what does any body do.

it is a facilitator of anti-quarrel and reverse-logic, promulgated through experiential evocation.

I see. I travel. silver-silver and gold-gold are quiet. my senses reel. titanic vertical forces scream all around me. maybe continue experience. maybe disintegrate. the table had been ready for nearly an hour, the ship deathly silent but for the occasional gust of wind summoning disconcerting creaks from the floorboards. the players ready to begin, Admiral's flasks neatly in their cupboards, and Bevergius Baigle preened and sitting rigidly upright with signature grins spreading and vanishing. the two stared at one another as crewmembers took small samples of the large nugget on the 
pedestal with finely fashioned silver chisels, contents put into a mixing bowl, ground with mortar and pestle, loaded into two pipes the combatants, then smoked with feverish inhales, bits of nugget-flint crackling with white bright-spark and purple smoke.

the Admiral quickly became pale, sickened with nugget-blood parasite, poor Baigle sporting shades of green and yellow, whites of his eyes pink-watered. lavender vapors rolled out over upper teeth in a column from gaping mouths.

you first, master Baigle, the Admiral always offers to Baigle, after his expression of confusion subsides. he accepts each time with a great deal of reluctance, though ploys of the Admiral pluck-pull on his strings.

I insist, motioning with a wiggly finger. Baigle begins in tremulous voice.

I am to meet you at the Grasslands of our fair Lady Au Ju Carbonara, the mistress of the Dale.

this notion is a fallacy, sage-sage is always quick to whisper. the Admiral will counter with ease, no doubt!

someone that is me but maybe not me shushes sage-sage, the old man, and he bows his head.

Baigle's eyes go listless as he reels back and forth, staring off into nothing whilst maintaining the composure of an invalid. the Admiral says, you were to meet me at the Grasslands of our fair Lady Au Ju Carbonara, but she had denied your entrance to such lands after the prearranged, swift rape of her husband, Ferdinand Fuhksquire, whose mistress of the Dale had expired two fortnights previous. the Admiral takes a swig of brandy. Baigle does not tarry. my skin enjoys the vocal perturbations. in awaiting his response, my hairs erect as though their cells have 
sent them tiny letters of an intent to fuck. I send a memo reminding them to remain calm for the duration.

the Grasslands no longer exist within the realm of Lady Au Ju Carbonara, for her thrice-raped husband had bred three sons who one very dry summer had commissioned their removal, and the Dale was mistress to the Foothills.

the Admiral always chuckles at this juncture, throws back his head.

grass has raped the earth for far long enough, so at request of the Foothills I have found upon quest, for the sake of virgin maidens everywhere and who might not exist once their water supplies become carbonated, a realm of platitudes where the removal of impregnated commissions might beckon from the three suns the release of Lady $\mathrm{Au} \mathrm{Ju}$, the fairest of Dales.

Baigle never gives in so easily. my epidermis has begun squealing with microscopic queefs. a billion tiny queef-massages tantalize my outermost layer. the Admiral counters, sending my cells into a frenzy.

I meet you at the Grasslands, but you find that I am not where we were to meet, for the fairest of Rape has commissioned of me a removal of myself, my abode, and my properties from the corporeal world, and I have achieved that before I sent the message to you to meet me at the Grasslands. raping you at the Grasslands, you find that I am not in you; it is the Foothills, and the Dale is laughing a landslide into your bowels, and I have not met you, for I had decommissioned myself back from my commissioning a removal of myself, and now having no longer been removed, have met you at the Grasslands. Ferdinand, the Carbonara of the finest Carbonara's has invited me on a voyage beyond the horizon. I eat a chocolate souffle while you vainly attempt to halt the defecations of a 
mountain, and whilst thinking of your daughter who is alone and lying in a pool of abortions, denies herself the knowledge of you and instead begins drawing her masterwork, the genius blueprints of my destiny in a schematic that is easy to read by Lady $\mathrm{Au} \mathrm{Ju}$, who after my departure has stopped by to show you the most potent antidiarrheal known in all the lands. I meet you in the Grasslands, and I drink your medicine. sense no difference between the air and the exhale of my skin, feel no boundary between bone, muscle or dermis. a fortification of pleasure, rivulets of circulating exhilaration.

Baigle's previous riposte, the intricacies of the parlance unfolding intraphysiognomatically, afraid to breathe too heavily, my lungs acquire the irrational fear that the perturbations of carbonated exhale somehow disturbs the delicate balance between the two, between the odd shifts in the space, between dimensions of person, between myself and my body's self that has infiltrated my psyche. it is strange, always so strange, though for some reason I know that Baigle knows that I know he wants the Admiral to win and enter us all.

it moves beyond the table now, beyond the voices, beyond the bodies, beyond containment. lights illuminate beyond the veil of where the light fell, my cells are their own universes, and all creatures within them cry out in their orgiastic culminations, their gametes slithering to collide in ekpyrotic singularities, dyadic dual-helix ouroboros, and the room floats beyond the subtle hold of the ship.

This was all new territory. This was a transformation. A clearing out. the Admiral opened his mouth, and before first syllable uttered, it became, as it always became, all too clear as to why he'd sealed this room from the rest of the ship. 
he'd sought to open a forbidden door, and he began taking them all down a most enigmatic corridor.

the Grasslands are a figment of the imagination of Lady $\mathrm{Au} \mathrm{Ju}$, he began softly, maintaining daring gaze that sage-sage couldn't match, and silver-silver and gold-gold wouldn't match, since they had only abstract eyes, the Admiral intensified with rising voice and red hot glow of ember occupied his lurid, dark volcanic gaze, curtain-roiling smoke drifting on his cinder-breath with the slow burn of patient malevolence, cosmicwary vindication.

she is the first of many daughters you have imagined to foster after witnessing many abortions, but this has come to pass in the Grasslands, where I have departed and arrived, for every prearranged raping of your miserable king and father's wife, Ferdinand Fuhksquire. you wax philosophical at the Foothills, imagining the imagination of yourself in the Grasslands, where I have been living for ten thousand years times ten thousand years. you discern that I am the Grasslands, for I comprise a mind for every miniscule thought managed across infinite worlds parallel to your contemplation at the Foothills.

this reality is but a pebble, a wayward servant who makes souffles for himself at each inevitable contemplation arisen, in those who have only dreamed of your apparition as easily forgotten nightmares.

nightmares, a single blade of grass, and for one blade of grass in the Grasslands, the number of thoughts possessed for every second upon the worlds made of Grassland in those contemplations

from those nightmares of your apparition, I appeared in each souffle from those worlds within the pebble, the forever of your thoughts overcome by my thoughts, in the 
imagination of your imagined self at the Foothills. the rape you so fondly speak of, it was eons ago, in a sequence of consumption that led to the word 'beverage,' your name, and it was studied vigorously, countless lifetimes hypothesized determined the chocolate souffle be constituted of children who are the defecations of a mountain impregnated with feeblemindedness, allowed to ferment, expelled, and then carefully calculated into blueprints. you were given these blueprints, and you studied them relentlessly, fashioning your mind round its concepts religiously even though you had no idea how to read them, you scoured the world in search of a medicine that was alluded to in a drawing of the blueprints made by the random scattering of horse manure on the cobblestones of a candy factory retrospective contemplation this wooden basket, in a flower shop on the day you feel that knowing yourself had attained its greatest state, you glance through a sunlit window glimpse for a brief moment a version of yourself unrecognized, 
a mirage in the pane

ghastly

understanding that from this world lies many doorways into dimensions not very

far from this one. but you fail, Baigle, to surmise that distance is not a factor in reaching them. the ability to properly taste excrement is.

Bevergius always struggles to maintain his composure, and upon hearing the final words of Petri's astonishing retort, he explodes in profuse vomit-whimpers.

the china, silverware, and crystal glasses all exquisitely crafted, and I only imagine what horrible wealth must possess us.

my cells calm, my body stills.

the music fades away, the lights on the ornate chandeliers dim to a soft hum, and my attention shifts from the hushing crowd to the center of some space, where someone I finally recognize appears in a skin-tight ballet outfit, chest diamond-studded, heart pulsing fusion star, spectacular celestial starscape-fabric dark blue, like just one part of his lips, a constellation of silver glittering round his eyes, and told as child, planets push us through the ages wild winds whisper leaves filaments and red-loosed in fray ember-purged from gold-gold's brazier tonight, in blue bosom's field an arcade of stars fixed dim, pinholed the candelabra from my cabin 
perched on window sill

show the way

scope heaven's bound

listen for light

mirror winks in the black

infant streaks electric-green

friends old, friends new

monuments of the screen

return in white wheels

tempestuous trifling dragonflies,

though not one fleck, not one twinkle

no wayward dashing beam or seraph lost

across the expanse of endless night-sea-

only light-years of emptiness

translucent

symphony of raven, wind, and onyx

all still.

I know there will be silence from the white mansion, dull songs from the forest fog that wafts and waters to the field in spill, slow, calculating, hostile-fire ants trickling, red carpet-puddle, splatter our shins when running through, and there will be blood too in the flutters of swallows fleeting through the willows in the fog, prophesying more, desperate, whispering of a peaceful dawn never born, only dreamed. 
on their wings, echoes of the spectral stellar wind, the death-knell cold in black, the forever-ghosts of stardust in the forgotten, silenced universe.

snapped then into action-bolt of lightning, striking elastic poses, flailing and frolicking from table to table with the crescendos of the vivacious music, moaning in pleasure, his slippers making not one sound on the hardwood floors.

he took up sticks from the floor with red and gold ribbons and danced, twirling them around his body and over the tables of the guests, who appeared completely entranced by his hurricane spectacle. The sounds of his voice became more erratic, more forceful and climactic, and sweating profusely, lightheaded, blaring music, coalescing with orgasmic fervor the sounds drawn out, diamond-chested and radiant, diamonddiamond, lights morph and distend, and I find the space shifting, lurching from one side to the other like the rocking of a ship at sea, or someone's child, body caught in a pure rapture of tearing himself apart.

red. only red. it was in the air, imbued the candlelight — infiltrated all corners of vision, draped over as would a transparent cloth. There were people in front of me, laughing, drinking, feasting away on grapes and foul meat, wearing robes, crowns and jewels like they were from the days of ancient kings, queens, knights, maidens all. ah, it seems that you have decided to join us, says the Admiral, seated across from me.

fingertips tingle.

a large feast set before us on the table.

oh! golden curls shivering as I clasp both hands firmly near a rosy cheek, exclaiming, sir $\mathrm{OH}$ has arrived! the patrons appeared unsure of how to react, and looked 
to Lord Infiniton for direction. sir $\mathrm{OH}$ had never attended a feast, had only conjectured that he might attend, but it was left to certain ambiguity and possible contrivance, as Sir $\mathrm{OH}$ was prone to abscond with congenial language and weave arabesque verbiage riddled with inconsistencies and outright incredulity.

on that day, come what may, FEAST I SAY, to crave, a stay . . . a stay, perhaps, but today, I plunder pox ridden ass — touche! he would say, then gallop away on his steed.

oh, sir $\mathrm{OH}$, Lord Infiniton bellowed, wiping his greased chin with the bloodied rags of former servant's attire, the surprise in his eyes matched only by the moment in his life when he'd first laid eyes upon a roasted boar served to him as an infant.

the Lord took in the countenance of the most splendid gentleman. His suit was of the finest material, a blue and pink pin-striped coloring, his black, pointy facial hair immaculately shaped, head adorned with a protruding oval hat with a large dimple in the center. The Sir threw back his brightly colored yellow cape and struck a rigid pose, tilting his nose upward.

Lord Infiniton, he spoke, commanding the loose chatter wafting through the hall be silenced, I've abandoned my duties of imprinting the terrified faces of children upon your cherry pies to bring you the most gravest of news!

pray thee, do tell! the Lord rumbled, attempting to calm his nerves by quickly snatching another crispy pheasant to nibble upon. it would be most unfortunate to no longer have Sir OH's 'Pictopies of Childmongering' at his wonton behest.

my liege of avoirdupois measure, 'tis past the time of your leisure, and count upon the quickly pervading sensibilities of mine to trine thine mind of immense and dispensed 
pleasure, odoriferous countermeasures must I of you implore, to console the dole and assumed sole contorted supposed contortions proliferating as we speak about your land! we've no time for these theatrics, Sir OH! the Lord snapped, slamming his empty goblet into the crown of a passing servant's head, for it should have never been allowed to drain. the crack of the servant's skull, rather audible, as though it were a large walnut or seashell that had split, and the guests turned to regard the screaming, thrashing spectacle as dark crimson began to gush from the wound, his eyes, ears, and of course mouth. Blinded and gargling, the servant staggered closer to Lord Infiniton, who promptly jerked his golden chalice from the man's skull, taking with it a large portion, which he examined out of curiosity, then declared robustly to the legendary Chef Shawarmi Sol to be a fine piece of cranium mignon.

my liege, another servant offered, what I believe Sir OH is most generously informing us of, is that an army of Chorgs is soon to lay siege upon this castle! don't be ridiculous, the Lord laughed, shoving a handful of the Salad of Mirth into the servant's mouth so forcefully that several teeth tumbled into his airway, face then filled with shock as he clutched his throat in vain, Lord Infiniton screaming for him to swallow with such tremendous gusto that the words scalped the man and tore the flesh from his face. and all the guests were privy to a very surprised, wide-eyed, lipless carapace that began chortling uproariously just before a suction collapsed his cranium and jets of steaming green foam sprayed across the banquet hall from his rupturing torso.

tis true, Sir OH confirmed, and Lord Infiniton's laughter subsided, his eyes quivering. He slammed a fist onto the table, shouting, bring out the Vagiquaff! 
to those unaware, it was quickly explained by the Lord that this new threat to their feast would be dealt with in the only manner known. the Chorgs were a riotous bunch, when more than one of them were present, the only solution a unique stroking method that Lord Infiniton had perfected when capturing his very own Chorg. he'd learned the technique from the diaries of the recently deceased Lord Heigelburg Flatulon, one of the feast hall's most beloved alumni. a dozen soldiers came swiftly from the rear entrance of the hall, carrying what appeared to be a large iron tank. General Chowderburg led them, strutting whilst tamping a cane to the beat of his step. the blonde-haired brute slicked back a portion of his plied, greasy hair that had come loose, tugging on the bottom of his uniform.

my Lord, the Chorgs have arrived and have commenced defacing our castle walls with their plentiful excretions.

send the townsfolk of Hillsbrook to serve as a temporary blockade against the beasts, the Lord casually ordered, motioning for the table to be withdrawn enough for the tank to be brought closer.

lady Vulvatarius, are you ready? Baron Brunchley inquired, assisting his Lord by inserting the mysterious iron tank's nozzle into the Lady's gusty orifice.

but, my Lord, the general began. wouldn't that severely dampen our reserves of potential servants?

clearly you have forgotten our steely reserves provided by the grandiloquent coffers of Chancellor Diktitts, for my most generous display of consuming an entire hundred courses! 
it was spoken then, as was usually spoken, with such gusto that the Lord would have surely slain his most trusted man had he not turned his head, the breath peeling paint from the walls. frustrated with the question, the Lord snatched a tall, thin servant by the throat instead, and began twirling his body in a circular fashion whilst holding fast to his neck. centripetal exertions ejected the man's skeleton and innards in concentrated spray, a mist and then a cloud, pulled into the current of the ceiling fans.

the Lord tossed the flimsy skin aside, wiped his hand with a napkin.

I taste sideways, and silver-silver and gold-gold enter once again into the foray. sage-sage nods his head in approval, and diamond-diamond shimmer so brightly I can hardly see. the perfunctory compulsions within me rise transfiguratively towards a crescendo of gyrating bundles of intellectual liquidity, completely devoid of enigmatic quality, idiosyncratic ambiguity, all coalescing into quintessentially ostentatious trajectories amidst fluctuating emulsifications of my body, immersed within the sexual conduitis of this mechanism.

kwee! I screech, my bones rip into fire, and with a hasty lick now considerately understood in the face of all possible speculation, a pelvic thrusting of the universe, thrusting the universe, languishing to multidimensional orifices, confounded, pernicious kings and queens of holographic projections, galactic prelapsarian cock-tease! analyses projected precisely this amalgamation, but oh, mere conjecture made manifest this compulsion, uniformed cosmos, my answer to the dilemma, a new language, a new word, a new universe .... 
and yet with great joy in our hearts we gleefully followed after Mrs. Fuhksquire, eager to experience the salacious pleasures that she promised us on that most desirable boulevard not too far ahead.

Lord von Kunt, having been instructed to wait for us, squealed in his common manner as we drew near, his petticoat already soaked by a strange effulgence spewing from between his legs.

ha-ha! laughed Mrs. Fuhksquire. clearly the joys that lie ahead have proven too much for my companion! I had best tend to his needs! with a great flourish, she tore the clothing from her voluptuous body, revealing something we had all suspected but dare not say

with a roar that would forever haunt my dreams, provided I not perish in the forthcoming hailstorm of fornication, Mrs. Fuhksquire flung herself at the elegant Lord, not even bothering to disrobe him, her engorged member throbbing eagerly as it punctured layers of soaked cloth to bury itself in his mystical orifice. we applauded, clapping our hands and jumping about, giddy as schoolchildren, as we were about to get the first taste of real human delights.

go now, whilst I entertain my mistress! mrs. Fuhksquire commanded, thrusting like a jackhammer, causing Lord von Kunt to issue great spurts of fluid onto the cobblestones. though I was sad to tear my gaze from the Lord's delectable fucking, I knew that what awaited stretched beyond my wildest dreams and I was satisfied that the man's cunt was receiving a sufficient porking, so I pranced after my fellows while gripping portions of my body with white-knuckled strength. my fellows couldn't wait and 
had thrust ahead of me, and I nearly slipped in the trails of pre-cum they left in their wake.

they disappeared around the street's corner, building my anticipation to a crescendo that stole my breath with its promise of orgasms beyond my fragile mind. a smell similar to that of a beach at low tide hovered in the air, the odor seeming to pour forth from the walls of the buildings themselves. I tightened my grip on my organs, which had long ago torn out and consumed the front of my trousers, and I bounded around the corner, struggling to hold onto my kidneys and spleen, which were somewhat of a bother for how bulbous and coated in a bloody seepage they were.

at last, I took a final few steps and the legendary feast of the Festering Boulevard sprawled out before me. the sight drove me to my knees, and as I sobbed, I dropped my organs into a misshapen pile and began to tug violently on myself, whining and groaning in painful pleasure of the knowledge I would never know again. I decorated my body with wrappings of my sticky juicy entrails in celebration, arising once again to my feet so that I might dance about with furious stroking and stinging glee with the sight spinning round and round my vision.

a jovial thrashing took over my body, my senses overwhelmed by the blur of writhing bodies stretching as far as the eye could see: they littered the streets, pressed and smeared through the steamed windows of businesses, and they were even strung along the walls of the buildings like garlands and banners so that the full pleasure of their message might be taken in. they must have noticed the newcomer, for their cacophony seemed alerted and directed towards me then, the noises and smells of that writhing congregation knocking me onto my back, forcing me to ejaculate precious juices that 
sailed from openings in my flesh, squirting into the air and landing atop my dress and face.

I wiped the bliss-cream from my eyes, sitting up so that I might attempt to take the sight in once more, but I was thrust back against the street by the shockwave of another fleshly issue from the crowd. in lying on my back, I saw something unlike anything before. I yanked a spyglass from my trousers, finding that this new configuration rose up before me like some apocryphal monument. a tear fled my eye as I looked unto the hordes of people entangled with one another in mighty pillars of flesh that looped and braided above me in the glittering, softly darkening day—arm-leg-limbgnarled and swirling together, the pillars shouldering a heavenly moon of these silversilver-gold-gold bodies consecrated to eternal rapture-tormented-diamond-fucking. the moon-jewel eclipses the amber sun.

I quickly began writing this vision into my notepad, taking great care to capture the moment on the glorious celestial orb when I witnessed an asshole stretch widely enough to accommodate at least forty-seven detached, air-bound cocks, the throbbing orifice gulping them up in one slavering slurp. I witnessed no fewer than seventy-two beings being pleasured simultaneously by one, their limb and tongue protrusions flagellating penetratingly and eventually, as I noticed from the haze building on my lens, blanketing me with a fine mist of their ecstasy.

frantic, I cast the spyglass aside and began tearing about the streets, desperate to catch as many of the divine droplets as I could so that some small part of God's orgy might be inside me. 
upon the first fuckful flavor, I began documenting the event once more, but my utensil was exhausted of life and shredded the paper. I turned it to my flesh, howling as I carved the letters to capture more of the wondrous details. my tongue danced and lapped around my mouth and 1 drug my tongue and my teeth over the feisty organ as though it were its own creature to be tamed. In my abdomen and legs, the wounds shifted and pulsed, the lettering opening and closing with a hunger that matched only the lingering flavors in my mouth, and torn between searching for more of the eternal cream and fingering the word-orifices opening all over my body, I cautiously pressed a pinky into one that read "DOGMAI," and while I didn't trust this course of action, it pouted and kissed ever so seductively. a teasing burning slipped through me as I withdrew the maroon-coated digit, and then I tried once more, and then I tried more fingers, and then I tried the other wondrous holes until I convulsed and squealed uncontrollably out in the open. fluids began weeping and spurting in hair-thin streams from every pore of my skin, and then I noticed that my companions had also succumbed to similar pleasures, having fallen upon one another in a frenzy of lust, furiously pounding and sucking the last-living fuck out of one another. I cast my eyes to the buildings, revealed to me now as fornicating fortifications composed of thousands of writhing creatures. their faces ripped and melted into one another in the buildings of flesh that moaned and swayed, spilled their fleshly juices into the gaping, thirsty holes of the streets amidst a cacophony of apocalyptic machination, the sounds of rusted colossal gears grinding, fabric ripping, flesh tearing, and infants squealing.

the sea of humanity shifted and distended. 
used, throbbing orifices in the street pulsated as though they begged to be filled, and I began ramming my fist into them, overcome by a newfound rage that I could not possibly satisfy them, let alone myself.

the wounds in my body were jealous then, and they began screaming at me to keep fucking them and the entire world was screaming at me to keep fucking them, but I pulled myself from the openings in the earth and flesh sloughed off to the bone but still I ran, having found eyes staring back at me from down in the gaping holes, eyes in my gaping flesh, and the bloodshot bulging eyes sprouted in vines and stalks from my skin and entered my mouth and pressed into my open eyes, attempting to forced their way into my head, and I tried to rip them away but the blood coated them through with a thick pungent slick and I cried out, tearing at the eyes and squeezing them until they broke free from my body or burst, and I drew near the frothing masses lining the streets, and the wounds made a new sound, a roar I'd never heard before, a ravenous pounding that hungered for more than my mind, and the crowd rang out with a chorus that was one with the wound, with the message that made my body not my own, and then a strong hand grabbed me by the shoulder and it all went still.

I turned to see Mrs. Fuhksquire standing over me, wet and bloodied and dripping on my only unblemished patch of pristine skin. Dazed, my senses wrought, a question lingered between myself and the earth, because I had needed a new sound for my wounds, and I had gone into the wound, had opened it forcefully and carelessly, and the Lady Admiral must have known what would happen, for she merely cooed and spread a stripe of sweet whip across my trembling lips from her breasts which foamed profoundly. mrs. Fuksquire, might I stay with you forever? I beckoned. 
why, of course, my child.

and what of our companions? I inquired. My body was restored and I savored the sweetness, but as I attempted to meet her gaze my mind halted, still locked in the memory of the vision.

they're far too succumbed to their own meat, she said.

the Lady Admiral laughs as she always does, gesturing at the orifice-riddled bodies of our associates, the myriad members that grow from their flesh and tear it apart still pulsing with desire.

Lady Admiral commands me to find Lord Von Kunt and bring him along, as he is in no condition to walk for a fit of giggles that overtake him at the culmination of their intercourse. I find the disheveled Lord lying in a pool of issue, and he cackles with such fervor that I too am infected, and we rejoin the Lady Admiral, our laughter dancing along the flesh of the street.

all artifacts left behind, and in the body, nestled words, spaces, sensations, vestigial unknowns, cacophony, mirage, memory, anguish, anger, and wonder, carriages ferrying thoughts, beings, and realities to and fro, cultivated,

as if to show the road back

did we forget the way

did we tumble from the hillside, down verdant bands

into silvery sheen

into gold and dance

into abundant never-filled 
wandering towards the never-now

blind to tomorrow

open to yesterday's always. 


\section{CHAPTER IV}

\section{BIRTH CARNIVAL}

John fists Randi gingerly as they wait on the sofa for their haircuts. She winces at the girth of his wrist, but somewhere in her strain and perspiration, Benjamin sees trust and endearment. The straps binding him to the barber's chair aren't too tight - just the right level of security, the right level of discomfort, something he lives with — and not to mention the vantage point. He's only a couple feet away. What a great place to be sitting for just this kind sight.

The sable curls of Randi's black soaked hair cling to her forehead, and John says, "I love you, Randi," while turning his hairy wrist, and Benjamin sees Randi pause, writhe, and sigh. She believes John with her tears.

Benjamin can't help but let one loose himself, but not because it moves him to cry. He needs his imagination to help him understand their love. He needs more thoughts than what the sight can show him in order to feel some kind of way.

Benjamin would like to know if there is something closer than feelings, something simpler that his mind might wrap around. He's quite occupied as it is, strapped into the barber's chair, trying to trim his own hairs.

He imagines that a barber would hold the clippers dangerously close, just slightly nipping at the hairs, the buzzing coming closer and closer to his ear, and then the clippers would draw back to some point behind Benjamin's head, and the barber would whisper 
gently into his ear then, "Don't worry, I'm not going to take too much off. You're going to look great."

That pleases Benjamin. It will be nice to look great. He used to dress up when he visited the carnival, but not so much anymore, since people seem to care more about his head than anything.

He made quite a mess last time, thinking he could cut his own hair. He'd gotten carried away, pulling and pulling the hairs, savoring each one, getting caught up in the sensations of it all, the pin-pricking tingling feeling of each strand as it popped loose from his scalp, and then he realized that he'd just lost track again and that there was a big, saucer-dish patch of bare skin on the top of his head, enough hair in the carpet to swipe his fingers through it and pluck up a big clump. He'd tried combing the rest of his hair in all different places to cover it up, but it was no use, so he went in with the clippers, shaving and shaving until his white skin grated loose, again and again through tight, smooth oily skin, ripping the white ribbons loose until he shaved red and bone. He had to. Everyone would've seen the big white patch of skin in the middle of his head and they would've all known that he'd gone and done it again, or they would've thought that he was sick and that they had better all try to avoid catching the bug, but Benjamin always feels a certain bugging at him, in his head. He feels the bug, even now. Sometimes likes the bug, likes chasing it deeper and deeper, but now it's burrowed too deep, too deep into the wound, and a wound doesn't always look like a wound, but it will make everyone else feel better if it does.

The metal teeth of the clippers vibrate Benjamin's skull as they nibble through the carpet of strands, snapping the keratin like dry spaghetti and plopping it in clumps onto 
his bare neck. The hair itches, and the sprinkling clippings rustle down to the plastic cloak that he has cocooned himself inside.

“Alright, I think we're all done here," the barber would say, and Benjamin would take the fat mirror from the tall man, while trying to avoid touching his skeletal fingers or looking into his gaunt face.

Benjamin inspects the patch where his hair had once been bald, having grown in thinly now and the short tufts of hair looking swell in the mirror, and he wonders if the glass is fibbing a bit to make him feel better.

He places the mirror in his lap and begins to run his fingers through the strands, tracking through the thick growth on the sides first, and it feels dense and strong and somewhat more tensile than the thin poor things on top that have had to grow and grow and regrow back again. Benjamin, grieved that he's had to take them out so much, plucks them like irresistible Daffodils or other spring flowers, where he can feel his skull beneath his fingers, and he knows the bug is always in there somewhere, and maybe if he tugs enough, maybe all the skin will peel right off the bone like the skin of an orange and he can pluck it out. He wonders what wonderful odors might burst forth when he does so. The hairs are soft and short enough to get a hold of, and this is dangerous. And exciting. What sort of fragrances are hiding just under the skin? In what juicy delights does that little bug scuttle?

Benjamin decides to see other attractions. John is up to his elbow in Randi, and when a lump forms in her stomach she closes her shivering hands around it and releases a long moan. Their faces press together and melt into an amalgamation of wriggling flesh that gasps, wheezes, and bubbles, the fleshy sounds forcing their way through the rubbery 
stretchy folds and goop. Benjamin gets up from the Barber's chair — not an easy thing to do - and he snatches up a handful of pink tickets and slinks towards the door of the white room, looking back just once more to Randi and John. They have torn themselves away from each other and sloughs of face have tumbled into a doughy pile on the floor. John and Randi stand, their lidless eyes and glistening meat pointed at Benjamin, John's arm drawing a crimson, splattery line across the floor as it slinks in a wet spill from Randi's abdomen.

Benjamin touches his genitals, noticing how they are at once stiff and soft. His chest is firm and strong, not delicate and supple like Randi's. His hair won't stick to his forehead when he's been raptured in a suffering pleasure. It's too short for that now, but his eyes might linger on his lover, might roll back into their sockets and into the mind, where the man who pleases Benjamin takes hold and molds and moves him with his own body. A jubilance can be found, he decides, then an ache springs from his lower back, and he thinks he might fall and will need to be carried.

Benjamin clenches the pink tickets, mashing and folding them in his grip as he pulls himself to stand in the sterile column of light bleeding from the open door.

Tents stipple the carnival landscape, orangey and striped and bulbous and protruding, sticking out in the darkness like candy. The air smells hot and gummy like a kind of syrupy spill, a strange mucus or some viscous sap. The clowns can dance and spin around in it effortlessly, and they bring their bulging bloodshot eyes and painted, surprised faces close. They shove sticky-sweet blue and pink popcorn sculptures in Benjamin's face. The clowns laugh, poking at his bottom and groin with the shafts, but it's easy to ignore their silly popcorn cocks. Their brushed-on emotions and overt 
gesticulations are far too serious to be taken seriously, and Benjamin presses onward. He feels a buzzing in his belly and grasps the tickets tighter, and he hopes the King will still accept them, moist from the sweat gathering in his palm.

The tent's curtain is heavy and purple, covered in blue diamonds, and Benjamin wants to very suavely dip inside in a fluid motion, but the heavy flap makes him fall and drop the tickets. The King sits in his checkered robe, red and white, his pouting rosy cheeks greeting Benjamin as he gathers the tickets back up. Benjamin hopes the King is excited to have him as a visitor again. The King says nothing until Benjamin hands over a ticket, and once it is in his fat fingers the King tilts his head to the side and grins, his yellowing hair matted and wild.

"Dearest friend, welcome!" the patriarch bellows.

"I could use some words of wisdom, my Lord," Benjamin says.

"With no morsel of doubt, young fetid," the King cries, slamming the base of his scrotal scepter to the arm of the brass throne.

A loud ring fills the chamber, and Benjamin notices how the sound struggles to travel through the thick humid air. "An adoration might better suit me," Benjamin suggests. The King goes silent, and Benjamin thinks he's done something terribly wrong, but then he sees an open palm. Benjamin hands over another ticket. The King becomes animated once again. Spittle flies in all directions from his ruby lips, and his painted eyes and luscious lashes flash wide.

"Then let this fine annunciation be extended to wreak such affect as to that which you endeavor your genitals might supply. My generous rising in the morn constitutes the very rising of our sun, as you know, and my symphonic exhalations drive asunder the 
lingering cretins of the baleful night. Yea, even the nature of truth is as constituted by my most ineffable, diarrhetic graciousness, as it is my exquisite, yet insouciant penile compulsions!"

"Yes, my Lord," Benjamin stammers, dropping to one knee. He hopes to speak this way someday. The King must know all secrets and mysteries of the yellowed, muddled mind. Surely the King might help him discover how to best inhabit his body, how to best seek after what he lacks.

Benjamin shakes and stammers, is caught off guard by his own excitement. "Your slightest prescience might deliver me! And where is our Queen? I had hoped to fancy your divine betrothal."

"The Queen lingers within her studies, young fetid, fancying herself as wellversed in the Breastoration Period as myself. Another ticket!" The King outstretches a grubby, glistening hand. Benjamin realizes he might not have enough tickets left to see the other attractions. When the crumpled ticket touches the King's palm, he jolts from the throne and saunters to a chartreuse organza curtain, throwing the shimmering cloth wide with great flourish.

The Queen lies prone, pearl belly bulging out from her opalescent dress, the fabric mottled with turquoise and silver, thick and rustling with her every slightest movement. She groans and daintily nibbles from a saucer of jelly-filled cream horns. "How lovely to see you again, Benjamin," she coos, her white bosoms pouring over the edge of excessive and choking fabrics, the threading and layers designed to prevent her gelatinous rolls from tearing through the seams and spilling out of the ornate dress. The Lady's glistening 
jewels chink together around her wrists as she pats at her billowing puff of golden hair between slurps.

The King shuffles back to his throne. He motions for another pink papery raffle. Benjamin obliges, and the King stuffs it inside his ruby robe. Benjamin's debt is hardly paid. The King lectures him once more, as he always does, warning that should he falter and recognize himself swallowed in the trepidations of backsliding and depravity that abounds this abhorrent land, he at least has the King's blessing to remember.

"May my assiduous, penile endeavors be imparted," the King continues, "so that they might embolden the frictions thou might administer unto thine own member, and yea, all such salacious copulations which are sure to ensue. But it is your nature I fear, for it is such that the vast swells - your oceans of thought—hardly comprise one droplet of my Lordship! You must worship me in ritual, in remembrance! Another ticket!"

“Truly?” Benjamin asks, handing one over.

The King nods vigorously. "I dare say, even your bowel movements will be most unpleasant without the glorious recall of my own excrement's blissful aromas."

"My Lord, this is kind advice," Benjamin says, bowing so lowly to the throne that his forehead touches the shiny black boot of the King. As soon as the silence returns, Benjamin offers another ticket. "But, if I may be so bold, I still feel as though I am lacking. I was really hoping for a new life. Really, I was.”

"Then let us ask my Queen, Benjamin, let us ask her!" The King slices with his arm to his Queen. She begins to rumble and groan, her her-ness stirring from its depths. Benjamin wonders if her her-ness is in response to the King, or if it's hers on its own. He wonders if she will fully her him with her essence or only bestow some gentle 
benevolence of her-ness to him, some her-ful graciousness. Benjamin's belly begins to buzz, and the King bursts into a fit of jovial laughter and applause.

"The Queen has deemed it fit to share her her! Dearest of all fetids, this is great news!" The King begins stroking himself fervently. "Let this newfound womb serve thee well."

Benjamin feels his belly as it burns and pulls and tears inside him, and he lifts his shirt to find strings stitching across his belly, compelling him to run a couple fingers over the tender seam of black threads and bruised, blue-purple flesh.

Benjamin shudders his finger search over the fresh supple swelling, and they frantically hand another ticket over to the King. "Where should I go?" they ask, "What should I do?"

The King leans back into his throne, turns his golden goblet up and pours, crimson ribbons of wine streaming down each side of his chin. "I hear the Fartwindium Peligroso attracts a fragrant crowd this time of year," he says, exploding into a laughter fit.

Benjamin bows before exiting, making not "his" way, but "their" way along the promenade. They gaze over the landscape, gently patting at the tender wound where the womb was sewn into them. They take up the King's advice and step with some measure of caution towards a spectacle of lights and sound not far ahead.

The Fartwindium Peligroso pops and bustles with exciting exhales and gasps, perfumes and plops. A feathery plume of white gas seeps from the entrance when Benjamin tries to peek inside the curtain, but the ticket-man's stiff arm blocks the way. 
The tent wobbles back and forth as voices inside rise and panic to the pitch of screaming wind, then fall with fright at thundering crashing beats.

It all seems warm and inviting yet dangerous and exciting, peligro and windium, and Benjamin wants to get inside that wonderful bursting flatulence, but the ticket-man won't take the tickets. He just stands there with a big frown, a big stupid frown, and Benjamin pushes the tickets forward again to show him that they belong, but the stupid ticket-man shoves again and shakes his big dumb head.

"But I have enough," Benjamin pleads, but the ticket-man keeps his arm outstretched and shakes.

"You don't have the look, Benji," the ticket-man says. "You should go home."

"I don't understand. What look? I know I don't have many tickets, but the King gave me his blessing, and the Queen gave me a new womb to make a life — and I have the tickets to get inside!"

"It's not about the tickets. Everyone has voted and decided you're not the right fit."

Benjamin slinks away from the bubbling tent and feels for the stitches. The stitches are thin and tight, but soft, and they can just barely get their fingers around them, and they start plucking, start plucking, murmuring "Her, her, her, her," and one stitch comes loose as they back away from the tent, then another comes loose and they back away a little more. "Her her her her." The Fartwindium Peligroso bustles with pops, cracks, and hims hims hims him. Another strand plucks loose, and Benjamin's belly bursts and their insides spurt and spill, coating the grass with a puddle of swirling white 
and red. They fall to their knees and begin howling, sweeping their hands through the fertile milk to scour it up and put it back inside the gaping mouth in their belly.

There is a new emptiness, and the bones shiver, hug and cradle themselves and look away. Benjamin slumps into a strange pile, and it seems the skin must be going too, because the air suddenly stabs and bites and everyone walks past and stares at the sticky soupy mess. Benjamin tries to speak, but vocal cords just don't work in this way, and they can't hear over the buzzing of the bug, and they wish they would've stayed with John and Randi for just a little longer. The carnival was a bad decision, but there weren't any other decisions. They thought this must have been true, but now their own bones and skin didn't love them anymore and had decided to go on alone. The flesh clings to the frame, draping each bone with its thin veil of warmth, and the hollow sockets glance back at Benjamin before passing by the ticket-man, who lets them inside the comfort of the carnival's gas. 


\section{CHAPTER V \\ COSMOS T(EX)T MACHINA}

Emmett changed channels on the TV, anxious to see what had transformed astronomers' bewilderment to terror. In the top three quarters of the screen, a ponytailed, pale blonde woman whose highlights were starting to dull scanned her bleakly encircled eyes across a prepared statement at a lectern, while a multitude of reporters' heads were shelved at the bottom. Emmett scooted closer, his mouth hanging open as the woman's words began to drone out for many audiences.

"Preliminary examinations have determined, within marginal range of error, that the anomaly approached our solar system at rates in excess the speed of light, had slowed and dropped into an elongated, elliptical orbit. As you can see here__"

"Boy, can't you watch this on your iPad?"

His mom was being a TV-hog.

"I don't wanna watch it on the ipad. Plus I want you to see this too."

"I don't care nuthin' 'bout what these people are sayin'."

"Shh! Mom, they're scientists, alright? Something's happening."

"Mmhmm."

Images of the 'anomaly' appeared on a screen behind the woman speaking, and she pointed at a blackened, blurry region in the blanket of white and yellow-clustered 
orbs, where it looked like someone had scrawled the universe on an Etch-A-Sketch and started shaking it. The screen on Emmett's phone illuminated with a buzz.

\author{
Monday, February $13^{\text {th }}, 2017$ at 5:13pm \\ where are you, home? \\ did you find it \\ yeah $u$ watchin \\ no dad showed me yesterday \\ remember
}

o yeah

That's right. Emmett had asked to see them too, but Mr. Baldwin said that he didn't want the pictures to give him nightmares too. They wouldn't have. Emmett's mom didn't have time to monitor him like Martie's. Emmett hadn't been able to find much about the anomaly on the internet, though. Amateur astronomers didn't have telescopes powerful enough. He wasn't about to miss the press conference, but the nerdy white lady wasn't saying much.

$$
\begin{aligned}
& \text { Monday, February } 13^{\text {th }}, 2017 \text { at } 7: 17 \mathrm{pm} \\
& \text { ur dad find out anything else }
\end{aligned}
$$

\title{
hold on
}

he says they can't talk about it

so no i guess 
damn...

they hidin shit

$i k r$

Thursday, February $16^{\text {th }}, 2017$ at 11:21pm

what you doing tomorrow

\author{
practice \\ then tutoring? \\ ill be all hot $n$ sweaty $: D$
}

when, like 6?

and eww plz shower

yeah $i$ got $u$

but is that a good or bad eww

$i$ mean we will be sweaty ltr anyways

think so?

umm yeah, you owe me, valentine

lolololol

yeah, sorry bout that, lol

k lemme ask

lol like u gotta

Monday, February $17^{\text {th }}, 2017$ at $12: 21 \mathrm{am}$

ok it's cool 
isnt it always

ur dad luvs me more

yeah but you don't sleep with him

touche

God, like some unruly child, was erasing another failure. Something like that. Mr. Baldwin laughed when Emmett repeated what his mom had said. Emmett's mom was a doctor too, but not in astronomy, so they understood it a different way. The internet had its own opinions. Some people on there said it was Armageddon, Judgement Day, while others said it was Nibiru returning with the Annunaki.

Emmett had spent most of the summer researching them. The Bible stuff he knew a lot about, thanks to mom, but Nibiru and the Annunaki, that was something new, and it made a whole lot more sense to Emmett. Nibiru was a brown dwarf with a really strong gravitational field that moved in and out of the solar system every 3750 years or so. It had multiple planets orbiting it, and one of those the Annunaki lived on. It was like a minisolar system, plowing right through another one. The Annunaki liked gold, and in the past when their planetary system came through, they made a pit-stop on Earth for a few decades and made the humans dig. The Annunaki were at least ten feet tall, but some of the older, stronger ones were over twenty or more. That's why the Egyptian Pharaohs and the Assyrian kings were drawn so huge. The tradition began with capturing the likeness of the Annunaki, and this has been going on for much longer than recorded history. The people online said that the Annunaki use their ships to show up early, and they put a whole lot of people on lifeboats in space, but not everyone, because the planet gets 
wrecked with earthquakes over ten on the Richter Scale, and mile-high tsunamis from Nibiru's gravity, but before all of that, electromagnetic discharges will fry all of the electronics on Earth and the weather will go completely wack. At least, that's what it said on the internet.

\author{
Tuesday, February $28^{\text {th }}, 2017$ at 10:04pm \\ dude this is wack \\ $i$ know $i$ wish they told my dad more \\ i just want to know what it is \\ lucky they found it so soon
}

u think so

i hope so

That's what Martie said when something big was happening but he was keeping his excitement careful ... when he still cared to answer quickly.

\author{
does it matter tho
}

Early last year, astronomers had thought they were seeing a new type of galaxy cluster-something with such mass and density that light simply bent around it. There were voids in deep space that Emmett read about, but Martie's dad said this was different. 
It was Martie's fifteenth birthday, so Emmett had come to stay the night, though that wasn't any different from so many other days. Martie's dad clasped his hands and stared ahead as he described the anomaly that was moving through space, as though some imaginary point in the crackling hearth caught in his gaze. His fingers unfurled with his words and Emmett imagined a strangling blackness slithering through space. His thighs tingled, the sofa's spongy cushion drawing them to sleep as the embers in the fireplace glowed on Martie's dad's glasses. The tingling seeped through Emmett's spine to the backs of his eyelids and pulled them down like actors dangling from stage curtains. He dreamed the void moving faster over some months, growing, a pool spilling over light years of the deep.

The sky vanished.

Emmett read more about it online. He went over to Martie's to talk to his dad, Emmett watching the astronomer cross out a new section of his cosmological map each time with a squeaking ripple of black ink.

"If we had a ship fast enough, this is where we could go," Martie's dad said, pointing to some location with his black sharpie in the Virgo cluster. He paused. "But we don't have any ships."

The boys pressed him for more information, so he played a recording from his phone, a recording of what it might sound like. Martie asked not to hear it again, but Emmett yearned to listen in repetition, as the sound of it was like water sizzling on a pane of glass and bursting, glass scraping and scraping, as though it came undone and returned to sand and silica. He imagined red pops and white wisps sprouting between the hissing and clunking in the astronomer's phone; the sounds of atoms being strangled. 
Saturday, March 11, 2017 at 5:13pm

hey $i$ was gonna come ovr

u home?

yeah

can $i$ come

Wednesday, March 11, 2017 at 6:04 pm

you were over last night

lol maybe i should move in i could be your wife officially

Wednesday, March 11, 2017 at 6:15pm

lol, right

that would go over well

maybe i miss $u$

Wednesday, March 11, 2017 at 6:23pm

...SO

Wednesday, March 11, 2017 at 6:41pm

not tonight doing homework

oh ok

tomorrow 
yeah

ok miss $u$

Wednesday, March 12, 2017 at 1:33am

night

Martie's dad said it was slowing down, so the "progress" ripples on the map got thinner over time. It seemed the curtain would stop, and it did for a while. When Emmett came over, he poked his head in the bedroom door, where Martie flipped through his chemistry notebook, the pages inked double-sided so they crinkled as he turned.

“Hey,” Emmett said.

"Hey."

"Your dad in his office?"

"Yeah," Martie answered. "You should see it now."

Emmett's dark speckled face lit up and he went straight to the map in the living room to look at the progress, then he must have gone to pester Martie's dad in his office, since about a half-hour went by before he came back. Martie kept flipping through his notebook. They had a test tomorrow and Emmett had come over on the premise of studying, but Martie knew they'd probably just end up "studying." Emmett kicked off his sneakers and plopped onto the bed next to him.

“Learn anything new?" Martie asked.

"Not really. Jus' that it's getting bigger. Where you at in this shit?" 


\section{"Chapter six."}

"The one with the quad-somethin' formula?"

"Yeah, quadratic."

"I forgot the song. I know it goes like Row-Row-Row Your Boat or somethin' though."

"Right. X equals opposite B, plus or minus the square root, of B-squared minus four $A$ C, divided by two- $A$."

"That's right, now I remember," he said. He stared at Martie until he shut his notebook, got up, and locked the door.

That night, they watched the last full moon immerse into the gloom. The pearl drowned in the vat of covetous black, leaving the arcade of stars half-cloaked. The night was going out.

“It's bein' stole away,” Emmett said, speaking into Martie's mouth.

Martie's legs squeezed Emmett's tighter, and his pale hand reached deeper into Emmett's braided mop, massaging his scalp with the aim to tease out more comforting thoughts, but it seemed he might be right. There would be no more white wheels, not a new fleck, twinkle, or wayward beam across the sky. The curdled night-sea, this new curious thing, it was endless deep. Martie turned and pulled Emmett on top. He couldn't drown in the cold emptiness if crushed by warmth.

"What's gonna happen to us?" Emmett asked, so close that he could feel Martie's eye lashes flicking against his cheek.

“Don’t talk about it anymore."

Emmett only wanted to feel the way their faces fit like puzzle pieces. 
He wanted to fall asleep in a braid and dream of the moon.

He dreamed his mother took them far away on a ship, but they became lost in cosmic fog.

As the sails of the dream-ship fell still upon leaving the last layer of the earth's undulating atmosphere, Emmett looked to the captain's wheel where his mother steered, her auburn ribbons of hair drifting in zero gravity, and she yanked a lever and the boat jolted and crackled with fire and lightning and surged forward toward a bubble that folded around them, enveloping all in a lurid green glow, and the dream-ship tunneled forward, and Emmett woke up cold and keeping his eyes shut, slid his hand through the covers and shifted, his body looking for comfort. Emmett opened to a white glare, Martie's ghostly shoulder blade creasing his back as he propped on his elbows, watching the TV.

People were leaving their countries as it became clear that it was "their turn." The two watched the frantic people in Brazil, where some got ahead of the trampling and dust and shouts, the people piled up high on the fences at the ports until they burst.

The void dipped down through the sky like goop and touched the planet somewhere near the southern tip of Argentina, in a big glob, and then the spin of the Earth ground to a halt, and Martie's dad said there should have been quakes, that everything should have been torn away like loose paper, and he shut the door to his office and didn't emerge for hours.

Nothing happened though, so they decided to go to school, and they watched it all day on the screens and everyone gathered around in huddles with suddenly quieter chatter and looked at the floor when they shuffled in the halls, and people must have gone to 
work, for the traffic seemed normal, though it moved a little slower, and later that afternoon Emmett went to practice like he always did, but coach wasn't as mean, so Emmett went home and fought with his mom over which channel to watch, because he thought she should be a little more angry that the stars were never coming back, that the black curtain had dropped in a glob and begun oozing just like Emmett dreamed it would.

On the high resolution TV, the government came in with its aircraft carriers, F$22 \mathrm{~s}$ and stealth bombers and hit the glob with lasers, rockets, and radio-waves, but all went inside and nothing came out. The glob just spread and coalesced like molasses, becoming an impenetrable pillar that grew wider and wider and wider over the sea. And then it stopped ... and when it stopped every living thing fled to the sea.

Tuesday, August 3, 2017 at 5:08pm

they said it would go around the earth

but it's not

this is it

$$
\begin{array}{r}
\text { i kno } \\
\text { looks like they got it all wrong } \\
\text { did u see it started snowin in florida }
\end{array}
$$

yeah

Tuesday, August 3, 2017 at 11:17pm

hows ur dad

depressed I think 
he's been buying food, canned stuff

i don't know why

People sailed east to the Cradle, thinking they could get away, but the gloom closed in all around them. Emmett dreamed of it covering many places all over the world, the seeping, gliding slurry folding over mountains, cities, oceans. He'd hoped to see the world with Martie - they'd promised each other to go to the same college, study abroad and travel across Europe for months on end. The transcending of certain borders ... always on his mind. Possibilities existed beyond what he knew. It was easy to imagine a future elsewhere, beyond the prison of knowing. He dreamed them on ships ... always on ships, and soon Emmett dreamed others with them, other people on the frigate made of rusted metal that bounced over the water and churned in the sea foam like a sick, speckled whale. The dreamed had different names for the gloom, but most simply called it "the goop." Martie didn't have a name. In the dream, he said that people shouldn't have an obsession with explanation. When awake, Martie said not to talk about it, and then he would want to be held or he would hold Emmett tighter. Emmett asked Martie's dad every day about about the goop.

"Watching this drama gives us a whole new vision of the universe," he said one night.

Mr. Baldwin laughed at a name he'd heard given to it: "thief." The corners of his eyes forked into thick lines that branched across his temples-impossible lines beyond that.

"Why you laughin'?" Emmett asked, unable to erase his own smile. 
"It's funny."

"What's funny?"

Mr. Baldwin used his fingers to draw with the words, his hair salty and windflung with the motions.

"It's the last thing we'll know. The last song has struck the final note, and the singer is spent, trailing off into the last bit of reverb."

In Emmett's dreams, he sailed with Martie on an ocean of rippling glass and blue, and webs of white sunlight spindled and coursed atop the waves, like liquid crystal clustering and unfurling. But the boys' eyes were fixed on the horizon, on the starless space approaching fast.

Halfway through the planet, the goop stopped again.

Sunday, August 21, 2017 at 1:11am

hey, you up?

yeah

barely, lol

haven't seen you at school

Sunday, August 21, 2017 at 1:19am

i quit goin

mom said theres no reason

$w b u$

yeah but I may stop too 
there wont be school soon

its in mexico

they opened the border

Sunday, August 21, 2017 at 1:27am

i know, i saw

my dad was laughing at them

what? why

cuz theres nowhere to go

yeah

hmm so $i$ saw they put sumthin in it then they tried to take it out

Sunday, August 21, 2017 at 1:33am

what happened?

everythin that went in stayed

fuck

theyre sayin things get weird that close

the phones go out

everythin goes out

makes sense

i guess

what makes sense anymore 
us $i$ hope

Sunday, August 21, 2017 at 1:41am

yeah...

so you coming over or not

geez pushy

how bout sayin sumthin nicer

what like I love you

...well that would be a start mr
if u cant say it at least type it

Sunday, August 21, 2017 at 2:07am

plz come over beary-bear

I really really miss $u$

Sunday, August 21, 2017 at 2:13am

…..........

what

$>:($

are you mad now

no

$i$ dont do that no more

I'm sorry 
no $u$ aint $u$ on tht bs

dont worry white boi

$u$ wanna get a nut i'll get $u$ a nut

don't be like that

like what

you're not like that to me

ok so what then

what am $i$

I want to say it at the right time

$o k ?$

theres no right time left

you don't have to come ovr

when do i nvr wanna

omw

alrighty, lol

gimme 5

maybe 10

walking?

lol duh

haven't found that fucker

who stole my bike

lol you know you won't

it's long gone 
take mine

Inever use it

$$
\text { probably }
$$

oh ok thnx

and hurry plz

before the earth disappears

"It's been getting all fucky," Mr. Baldwin said, dragging his finger over the tablet. "It's still playing music alright."

Emmett had heard the piece before, but this time the chorus seemed terrifying.

"His ninth symphony always sounded like the end of the world to me," Mr.

Baldwin said. "What do you think? Should this be playing when it scrapes us away?"

"Mr. B, that's fucked up a little."

"Right, well, y'know," he started, pausing the music and uncorking a bottle of red wine. He dropped the corkscrew and leaned down to get it. "It's supposed to be about joy and fraternity, not oblivion, so I can see your point, but it's a little, uh, blissfully ironic to me."

"Okay, I need you to break that down for me."

"Well," Mr. Baldwin sighed, pouring the Cabernet. He stared at Emmett, his fingers splayed across the countertop.

"You know what, fuck it." He took another glass from the cabinet and filled the bottom third, sliding it over. "Like this might be for you. Blissfully ironic." Emmett 
didn't question Martie's dad, didn't even cast him one wary glance. It coated his mouth in a dry and bitter slick of heat—nothing like what its vibrant plum color indicated.

"Not good? Yeah, maybe you'd like something sweeter."

"Nah, it's good. I like it. It's an acquired tasted, I get it."

"Well, it's all gone to shit, right? So I figure you should drink up. Should we get Martie too? I feel like you could use that, after you guys' little spat."

That made him look up. "You heard us?"

"Yeah, and the make-up sex after-which by the way, is probably the quietest make-up sex I've ever heard, but I heard it all the same."

"Uh ... I mean. How long have you known about us?"

Martie's dad laughed and shook his head. "Oh, maybe at some point it was the love-struck look on your face when Martie would answer the door, or maybe the forlorn good-byes."

"So you're not mad?"

"You know, I was going to say something, but then I figured, what does it matter? I've known about Martie for a while. He wouldn't ever talk to me about it, though. Honestly, his mother would've been a lot better at this. What do you think? What really matters?"

"I'm sorry, Mr. B," Emmett said, lowering his eyes.

"No, it’s alright," Mr. Baldwin assured,

Mr. Baldwin pursed his lips, shook his head and brushed the air with his hand. He re-filled his glass. “Don't sweat it. I mean, Martie doesn't know I know. I don't know if 
I'll talk to Martie. I want to hope that Martie would think he could talk to me, but who knows."

"What do you mean?"

"Did you tell your mom? Would you talk to her?"

"Yeah, I did—-but you know, Mr. B, she's a little old-fashioned, so she still be thinkin' I'm goin' through a phase or somethin'."

"Yeah, well, I wish I could say the same about Martie, but not for that I mean. That boy doesn't seem to feel much of anything, not since his mom left. What I'm saying is that I worry about you two. Not for Martie's sake, but for yours."

“I know . . . he's afraid, and that won’t change. But it won't stop me from tryin'."

"You know," Mr. Baldwin forced out, "he had planned a tenth. Beethoven. A tenth symphony."

"What was it gonna be like?" Emmett asked.

Mr. Baldwin shrugged. "I guess whatever he thought would come next."

"What do you think comes next, Mr. B?" Emmett asked, and seeing that Martie's dad perhaps didn't follow the precise train of thought, he continued. "Maybe you should let him know you know. Maybe you should make something matter. That's all I'm trying to do. Martie don't have to believe it. Only I do."

In Emmett's dream, the voices poured in and out, and despite Martie's insistence to the jovial nature of them, Emmett saw in the sounds pouring from the sea that the human beings were swept in a wave of goop, their bodies disappearing from sight like soap suds popping against water. The music intensified, the vocals overpowering in unison, the discord Emmett felt at the onset fading away, but he heard something 
exasperate, something incensed, and Martie whispered something, but he never meant for Emmett to hear.

The curtain spilled closer, and soon, nothing worked.

It happened on a Sunday morning, and Martie went through the house trying his phone, the TVs, his tablet, but the screens stayed dark. He looked for his dad, but he must have gone to his office. Martie paced back and forth, sat on the couch, then eventually resigned himself to pouring a bowl of cereal when a frantic pounding rocked the front door, and upon opening it, he found an alarmed, wide-eyed Emmett waiting there.

"What happened?"

"My mom's gone."

"She left?"

Emmett shook his head. "Nah, man. She checked out early. Pills."

Martie didn't know what to say, so he hugged him. It didn't feel right at first, but then he'd never been squeezed that hard before. "Let me get my jacket."

"For what?"

“My dad's gone too. I think he went to his office. I don't think we should stay here. He's just a few blocks west. Will you help me look for him?"

Emmett's face drew worry. Martie hadn't given the situation enough time. Or maybe he hadn't done or said something he should have.

"I'm sorry about your mom, Em."

Emmett shrugged. Martie hugged him again. He didn't know what else to do. They walked down the street. 
The buildings were unlit, the cars rested like stones waiting for the next age, and there were no animal calls on the wind or even wind itself. Cast iron street posts that twisted like coat hangers, pitch black, reached up with clawed fingers, and the groans of the still city settled into the ground and fizzed up in a hiss. There was a pale, deranged daylight that morning, and a soft purple powder like flour fell in a haze, dusting the roofs, automobiles, and bodies lying in the streets. Bodies. They stopped, their eyes unable to pull away from the serene purple faces and resting limbs.

"They're all cowards," Martie said. "Let's go."

They made their way deeper into the city, saw that the people were arranged as though a gathering of them had piled in and slumped to their places during some commotion, like machines that had stopped working. Emmett wanted to stop, but Martie kept pulling him by the arm to lead him away. The thief was drawing near, but they couldn't see it for the haze.

“Martie, I was talkin' to your dad, and I think I know what he meant about all this," Emmett said. "There's some kind of joy to be found in this, since we're together, right?"

"It doesn't matter. Everything is nothing and will be forgotten. I want to try and find my dad. I know he's not here with these people. We have to move faster cause it's speeding up."

"I don't want to forget anything, Martie."

He stopped and turned.

Emmett couldn't see his eyes. 
White light refracted on each lens and hid them away. "You will, though. You can't remember where it's taking us, because we'll be nothing. Don't you get that?"

"We won't be nothing! We aren't fucking nothing! Do you get that?"

Martie didn't look upset, but perplexed. Emmett saw it then—gold and white particles drifting from their white and black pores like embers lazily wafting from a coal fire, as though they were stifled and dying.

"You see?" Martie said. "Even the light knows and is trying to get away." It emanated in what seemed languid and random at first, like drunken fireflies might, but then the particles found vigor and surged to some distance.

"No, it’s goin' somewhere," Emmet shook, taking his hand. "We can follow it! There are people running to it. Can't you hear them?"

Through the strange velvet ash the people whipped like cheetahs, and the drifty lavender flecks floating in pockets stirred as the people punched through the puffs of color. They were coated head to toe with the talc, and Emmett thought he heard laughter.

"Come with me."

"No."

Martie tried to pull away, but Emmett held him still. "Please," he whispered. It oozed closer, the curtain, emitting a sound they could hear now, a roilinggrinding at low pitch, stone upon stone emulsifying into a wash of silt and slurry. It moved like a hungry wave that slurped in the sea before its crest. Martie wrenched his hand free.

"You go on ahead. The last light is not far away. I know you can make it." When he ran, Emmett waited for him to turn around. 
Martie didn't, but still Emmett waited. He waited with his knees shaking, with his hands hot and numb, his stomach heavy like a wheelbarrow of brick perched on his gut, like he was full of the goop. He screamed in the purple ash until the grinding, too loud for him to hear, rumbled the earth underneath. Emmett sprinted down the street. The people had gathered in a square, poured in and huddled in a mass, were silent under the swirl of the goop as it closed in, swallowing up the buildings, haze, and screams. It all darkened and the goop rolled in like a flower blooming backward, and it all went inward, and Emmett reached for the last light beaming down from the top of the maelstrom. He fell then into it, without Martie, without anyone, into a strange sleep.

Alone, in plaid sheets, a ticking cuckoo clock jolted him to a start when it cooed. Emmett looked at his purple-smeared palm, noticed it caked under his fingernails too, and he sat there in his bed having the strange thought that he would hear Martie's voice or smell his morning coffee, but neither was there, so Emmett got up from the croaking mattress, a much sweeter smell rushing into his lungs.

Martie had baked some banana bread. Emmett looked down over the rim of his glasses towards the bedroom's doorway, tracing the sweet, nutty aroma with his eyes to the end of the hall, just to the left, and on the counter just next to the sink, there it rested, just like always, the loaf already cut and the soft slices resting atop one another in a gently toppled fashion. He placed the newspaper amid the tangled sheets and comforter, the mattress springs creaking and moaning as he turned and slipped his chilled feet into a pair of house shoes.

Martie stood at the sink, the lights off, her body and the walnut floors and cabinets gilded with an oddly white morning sunlight that bled through two windows 
above. Sloshing, soapy water mingled with the knocks and rings of silverware, Martie's tightly-curled head trained on the aluminum sink. She brought up a serrated bread knife, clumps of suds dropping in plops into the empty side. She rinsed and wiped the knife with a yellow towel, then guided the silver blade back into a chef's block.

“Always draggin' your feet," Martie said. Emmet slid his arms around her waist and pressed against her. He breathed on the nape of her neck and kissed.

'Don't be comin' round here in nothin' but your drawers, pushin' that thing up against me." Emmett tried to purr as he pushed again, but the sound came out as more of a garble.

“Go put some pants on!” Martie said, smacking his hairy brown leg with a soapy hand.

Emmett moved to the right, reaching for a slice of the bread.

"Uh-uh, get yourself a plate," she said, shooing his hand away. "I just swept up in here and I don't wanna see no crumbs."

He shuffled past her to the left and opened the cabinet to find a saucer. "Where's that granddaughter of ours?"

Martie looked up from the sink, searching out the window. "Still out there in that yard. Playin' with them dogs."

"Maggie called yet?"

"Yeah-huh—said it'd be five o'clock today."

"Shoot, I don't know about that." Emmett nestled the saucer and a napkin in his hands, his feet shuffling along the floor as he moved through the dining room towards the hall. 
"Tell me about it," Martie said. She had left the sink, was opening a door next to the dinner table. Her fingers kneaded into the knuckles of her other hand, then alternated. Emmett's knee flared up the longer he lingered.

"Girl, you better get up off of that ground! Oh, Lord, I'm gonna have to give her a bath now or she's gonna reek of them mutts. Why don't you do that when I bring her in? Emmett?"

Emmett appeared from the darkened hall, clawing his scruffy cheek. "I'll be in my office."

"Well, where else would you be?"

He scooted along, stopping in the bedroom to slip into some pajama pants, just as Martie had insisted, and once in his office, Emmett set the saucer and napkin down on his desk where a myriad of loose papers, paperweights, classic automobile magazines, dilapidated newspapers, and half-used pens lay strewn about. The cracked, flaking faux leather cushioning hissed as he eased into the green chair, and he tore a corner of the bread slice away, the mushy fluff dissolving between the roof of his mouth and tongue. Chunks of walnut found their way between his molars, where he crushed and savored slight bitter notes in the abundant banana sweetness. It must have taken so many people to make so many different things, he thought, rocking back and forth in the squeaky chair, attempting to summon the multitude of hands, intelligences, and fruitful intentions that went into the machined fabrications littering his office - purposed items that amounted an assemblage of chaos in his possession. The chrome spheres of a brass pendulum clock sheltered by a glass dome swiveled back and forth, books he'd never read leaned crookedly against one another on their shelves, in no particular order, and the 
shadows of some birds darted across the closed blinds. Laughter fluttered by next, Emmett's granddaughter Emma within faint earshot. He sat there, chewing, listening to the dishes as they clinked in the kitchen sink, the water rinsing, the dining room door opening, shutting, his granddaughter's voice pouring through the hall. The din spilled onward, crumbs lingered on the plate, and the blinds choked the sun into thin rays that ignited flecks of drifting dust like incandescent, lazy spicules, microscopic bulbs and motes.

Emmett rummaged through a bottom drawer of the scratched up wooden desk, his fingers fumbling in between empty folders and loose sheets until his digits finally closed around a firm object. He withdrew his hand, looking at the blackened stone not any larger than a tangerine, though quite heavy, a thin ribbon of gold dividing it into perfectly even hemispheres. The voices from the kitchen burst into laughter, and Emmett sighed, attempting to depress a knob at one of the poles, but it wouldn't budge. His attention drifted to the task of sifting through the wrinkled papers and crumpled magazines to make some sense of the disarray. The ache from his right knee distracted him, and following the pitter-patter of footsteps down the hall, Emmett glanced over his shoulder and found a pair of beady eyes peering through the cracked door of his office, Emma's baby teeth smiling back at him. The four year old pushed into the room, her little fingers going straight for a shimmering, electric-blue Morpho Didius butterfly imprisoned in a mold of acrylic.

"Now I know you don't think that's yours," Emmett said, taking it from her. Emma whined, her arms outstretched and fingers pinching together. He lifted her up to sit on his knee, the joint issuing a protest that migrated into his thigh. 
“Did you take a bath yet?" Emma shook her head furiously, her curls slapping Emmett on the face. "Are you gonna?"

"Nope!" she chirped, shaking again. She pointed at the butterfly, and Emmett picked it up, holding the frozen, glittery specimen in sight.

"How do you suppose that got in there?" he asked.

"They glued her!"

"Oh, so it's a she now, huh?"

"Yes."

"Why's that?"

"Maybe it's a boy, but I think it's a girl because it's too pretty to be a boy."

"And who says boys can't be pretty too?" Emma's light brown complexion creased and her studious eyes shot back and forth from the object to Emmett.

"Where did it come from, Pawpaw?"

"Oh, way down south in Costa Rica, I'd imagine, or South America."

"Did they catch it with a net?"

"Maybe."

Emmett put it back on the desk. Emma could be right, or she could be wrong. The helpless little bug may have struggled with countless dozens who were all lured by some sweet nectar into the trap. Or maybe they had all been bobbing in the treetops until a poisonous cloud of smoke had drifted up and smothered them. Had the cloud drifted with deceptive ease, or had it rushed in like a wave? It might have been the latter, and it seemed to Emmett then that a horrendous, putrid cloud would have rushed in like some malevolent force to the eyes of a butterfly, because he'd heard somewhere that tropical 
butterflies drank the tears of turtles, and he'd heard that it was due to the nourishment gained from the saltiness, from the minerals, and not from some romanticized fallacy of drinking away the turtles' long-suffering sadness, though Emmett liked the idea of that, but he considered the cloud, that indifferent torpor, must have seemed like a hurricane, an obliterating blast-wave to a creature that might drink a hundred times an hour.

In his dreams, Emmett couldn't escape from a wooden ship, one of an entire fleet, though instead of being tossed around in the ocean, the vessels stippled an imaginary blanket between cosmic, nebulous clouds. This indistinct cosmos, meant for marooning, swallowed up the stars and belched them back into lift before Emmett might sail towards them, while clouds grew and melded into strange turbulent effulgence. It billowed towards him, and Emmett could hear shouts and panic from the ships ahead. They vanished into the tremendous rolling wall, that operatic death curtain, the ripping of wood and sails and Emmett's own flesh deafening.

"Pawpaw, what is that?"

Emmett followed Emma's pointing finger. The gold ring belting the black stone had illuminated, ignited with an orangey glow. "Oh, that's just one of Pawpaw's things," he said, hoisting the girl from his lap before she could feel the pounding force inside his chest.

"You go on and go get Mawmaw to give you a bath now, you hear? Your mother's comin' to pick you up in a few hours."

"I don't wanna!" Emma shouted, standing in the doorway with a practiced look of despondence. 
"Go on now, and don't you make me tell you again." She was gone, and Emmett returned to the piece, studying the minute fluctuations of orange light in its gold belt.

"Please ... please let me get back to you," he whispered, but the button wouldn't depress, no matter how much of his strength that Emmett put into it, and he stared at it until Martie had turned off the bathtub faucet and the rhythmic column of water plunging into the tub ceased.

Emmett poked his head through the bathroom door. Martie knelt on the floor, struggling to get Emma's grass-stained jeans off. His wife looked up at him with a particular note of distress.

"Maggie's not coming," she said. "Take your shirt off, honey. Don't wait for me to do everything."

"Not like this hasn't happened before," Emmett said, leaning against the door frame with his arms crossed.

"No," Martie agreed. "But I thought we was past this."

"What did she say?"

"Said she had to take a double."

"Do you believe her?"

Martie pulled off Emma's last sock, looked up with her mouth agape. "Now what do you think? Do I believe her-what kind of a question is that? Did you put that dirty saucer in the sink?"

Emmett groaned and stepped away, heading back to the comforting, disheveled office. He slipped into a banana-bread dream, in which his bones burst into blood, grit, and fire. Disembodied, he watched the flesh of his form - fixed to some invisible cross- 
blacken beyond night. His arms and legs unraveled, ribbons of tissue and voided crimson plunging in a wash upon a glowing palatine floor. A glimmer of yellow light flickered from a fissure in his torso, but diminished, as though some tiny ark of weeping nestled within. His body appeared strange this way-this evisceration was strange. What he occupied ... unclear. Permitted to watch, it seemed, and then the chandeliered artifact that was his body, it disintegrated further, the sinew of his legs enshrouded by ravenous obsidian flame. These were strange flames that did not burn but issued a dullness through his flesh before it evaporated.

A tingle became a shudder through his spine, but his body was gone. If I am not there, where am I? he thought. The floor, peppered with remnants of blood and ash, drank them into its marbleized white and amber light, while the hum of the antechamber and the radiance- - lights within light and shapes within shape without any discernible station, always moving, always distending and breaking apart—at once coalesced, unfolded, and poured into the other.

The light involved itself in a visible direction, a concentration, welling itself into a space, a column that beckoned he speak, but before he could think But I can't it became more earnest, more beckoning with a mildly aggravated sound that surged forth in glittery sand.

The grains expanded, became their own minute kaleidoscopes of melody, geometry, and benevolent certainty as they compressed into a spherical machine of some kind. Do it, and Emmett did, from some unknown region, something formed between his non-existent throat and where it seemed the center of his mind should be. Emmett sank into the object, and the object into the column of convulsing humming light, and a voice 
uttered "This is not death and judgment, nor is this Death and Judgment, but something beyond their figment."

Emmett's dream about the ship in the goop, the object in the light, and his body in the burn snapped across his eyes with a flash when they opened, and Martie lay on his side, his freckled shoulders rising and falling with his lungs. Emmett slid his thumb off the switch of the orb, its gold belt holding a residual glow. He glanced away from it to see Martie staring back at him.

"Did you use that?" he asked.

"No."

"Promise?"

"Yeah."

"Liar."

Emmett dropped it on the floor and curled up next to Martie, staring into the gray light bleeding through the window. A burst of cold air washed the curtains.

hey

hey sup

what are you up to

nm jus chillin

$u$

nothing

wanna come over?

so now you miss me 
maybe :P

smartass

\section{alright im comin}

cool

and yes I miss you

$u$ better...

miss me like the world is ending

every day 


\section{REFERENCES}

Alaimo, Stacy. "Trans-Corporeal Feminisms and the Ethical Space of Nature." Material Feminisms. Ed. Stacy Alaimo and Susan Hekman. Bloomington: Indiana UP, 2008. (237-64). Print.

Alexander, Jeffrey C. Trauma: A Social Theory. Cambridge: Polity Press, 2012. Print.

Anzaldúa, Gloria. Borderlands/La Frontera: The New Mestia. San Fransisco: Aunt Lute P, 2007. Print.

Barad, Karen. "Posthumanist Performativity: Toward an Understanding of How Matter Comes To Matter." Material Feminisms. Ed. Stacy Alaimo and Susan Hekman. Bloomington: Indiana UP, 2008. (120-54). Print.

Barthelme, Donald. Sixty Stories. New York: Penguin Books, 1993. Print.

Bennett, Jane. "Systems and Things: On Vital Materialism and Object-Oriented Ontology." The Nonhuman Turn. Ed. Richard Grusin. Minneapolis: U of Minnesota P, 2015. 223-40. Print.

Bhaba, Homi K. The Location of Culture. London and New York: Routledge, 1994. Print.

Booth, Wayne C. The Rhetoric of Fiction: Second Edition. Chicago: U of Chicago P, 1983. Print.

Bordo, Susan. The Male Body: A New Look at Men in Public and in Private. New York: Farrar, Straus and Giroux, 1999. Print.

Brown, Adrienne Maree, Imarisha, Walida, eds. Octavia's Brood: Science Fiction Stories From Social Justice Movements. Oakland: AK Press, 2015. Print.

Bryant, Levi R. The Democracy of Objects. Ann Arbor: U of Michigan Library, 2011. Print.

Butler, Judith. "Critically Queer." The Routledge Queer Studies Reader. Ed. Donald E. Hall, Annamarie Jagose, with Andrea Bebell, and Susan Potter. London and New York: Routledge, 2013. Print. 18-31. Routledge Literature Readers. 
Caruth, Cathy, ed. Trauma: Explorations in Memory. Baltimore: Johns Hopkins UP, 1995. Print.

Caruth, Cathy. Unclaimed Experience: Trauma, Narrative, and History. Baltimore: Johns Hopkins UP, 1996. Print.

Chatman, Seymour. Story and Discourse: Narrative Structure in Fiction and Film. Ithaca and London: Cornell UP, 1978. Print.

Chen, Mel Y. Animacies: Biopolitics, Racial Mattering, and Queer Affect. Durham: Duke UP, 2012. Print.

Collins, Patricia H. Black Feminist Thought: Knowledge, Consciousness, and the Politics of Empowerment. $2^{\text {nd }}$ Ed. New York: Routledge, 2000. Print.

Dean, Tim. "Lacan Meets Queer Theory." The Routledge Queer Studies Reader. Ed. Donald E. Hall, Annamarie Jagose, with Andrea Bebell, and Susan Potter. London and New York: Routledge, 2013. Print. 150-62. Routledge Literature Readers.

Edelman, Lee. No Future: Queer Theory and the Death Drive. Ed. Michèle Aina Barale, Jonathan Goldberg, Michael Moon, and Eve Kosofsky Sedgwick. Durham: Duke UP, 2004. Print.

Hall, Donald E. "Introduction: The Queer Turn." The Routledge Queer Studies Reader. Ed. Donald E. Hall, Annamarie Jagose, with Andrea Bebell, and Susan Potter. London and New York: Routledge, 2013. Print. xiv-xx. Routledge Literature Readers.

Haraway, Donna J. "Otherworldly Conversations, Terran Topics, Local Terms.” Material Feminisms. Ed. Stacy Alaimo and Susan Hekman. Bloomington: Indiana UP, 2008. (157-87). Print.

Hennessey, Rosemary. “The Material of Sex.” The Routledge Queer Studies Reader. Ed. Donald E. Hall, Annamarie Jagose, with Andrea Bebell, and Susan Potter. London and New York: Routledge, 2013. Print. 134-49. Routledge Literature Readers.

Kaufmann, Jodi. “Trans-representation.” Qualitative Inquiry 16.2 (2010): 104-15. PDF file.

Le Guin, Ursula. The Left Hand of Darkness. New York: Ace Books, 1969. Print.

Márquez, Gabriel García. Innocent Eréndira and Other Stories. New York: Harper and Row, 1978. Print. 
Márquez, Gabriel García. One Hundred Years of Solitude. New York: Harper and Row, 1970. Print.

Mbembe, Achille. "Necropolitics." Biopolitics: A Reader. Ed. Timothy Campbell and Adam Sitze. Durham: Duke UP, 2013. (161-93). Print.

Montag, Warren. "Necro-economics: Adam Smith and Death in the Life of the Universal." Biopolitics: A Reader. Ed. Timothy Campbell and Adam Sitze. Durham: Duke UP, 2013. (193-214). Print.

Morgensen, Scott Lauria. Spaces Between Us: Queer Settler Colonialism and Indigenous Decolonization. London and Minneapolis: U of Minnesota P, 2011. Print.

Morton, Timothy. Hyperobjects: Philosophy and Ecology After the End of the World. Minneapolis: U of Minnesota P, 2013. Print.

Muñoz, José Eseban. Cruising Utopia: The Then and There of Queer Futurity. New York: New York UP, 2009. Print.

Myers, Walter Dean. Monster. New York: Harper Teen, 1999. Print.

Prosser, Jay. "Judith Butler: Queer Feminism, Transgender, and the Transubstantiation of Sex." The Routledge Queer Studies Reader. Ed. Donald E. Hall, Annamarie Jagose, with Andrea Bebell, and Susan Potter. London and New York: Routledge, 2013. Print. 32-59. Routledge Literature Readers.

Puar, Jasbir K. "Queer Times, Queer Assemblages.” The Routledge Queer Studies Reader. Ed. Donald E. Hall, Annamarie Jagose, with Andrea Bebell, and Susan Potter. London and New York: Routledge, 2013. Print. 515-28. Routledge Literature Readers.

Puar, Jasbir K. Terrorist Assemblages: Homonationalism in Queer Times. Durham: Duke UP, 2007. Print.

Rabelais, Francois. Gargantua and Pantagruel. Trans. Sir Thomas Urquhart of Cromarty and Peter Antony Motteux. Digireads.com P, 2009. Print.

Race, Kane. Pleasue Consuming Medicine: The Queer Politics of Drugs. Durham: Duke UP, 2009. Print.

Rubin, Gayle S. "Thinking Sex: Notes for a Radical Theory on the Politics of Sexuality." PDF file.

This Bridge Called My Back: Writings by Radical Women of Color. Ed. Gloria Anzaldúa and Cherríe Moraga. New York: Women of Color P, 1983. Print. 
This Bridge We Call Home: Radical Visions for Transformation. Ed. Gloria Anzaldúa and Analouise Keating. New York: Routledge, 2002. Print.

Sedgewick, Eve Kosofsky. "Queer and Now." The Routledge Queer Studies Reader. Ed. Donald E. Hall, Annamarie Jagose, with Andrea Bebell, and Susan Potter. London and New York: Routledge, 2013. Print. 3-17. Routledge Literature Readers.

Warner, Michael. The Trouble With Normal: Sex, Politics, and the Ethics of Queer Life. Cambridge and Massachusetts: Harvard UP, 1999. Print.

Xhonneux, Lies. "The Classic Coming Out Novel: Unacknowledged Challenges to the Heterosexual Mainstream.” College Literature 39.1 (2012): 94-118. PDF file. 